\title{
Effects of differential supplementation of fatty acids during the peripartum and breeding periods of Holstein cows: I. Uterine and metabolic responses, reproduction, and lactation
}

\author{
F. T. Silvestre, ${ }^{\star}$ T. S. M. Carvalho, ${ }^{\star}$ N. Francisco, ${ }^{\star}$ J. E. P. Santos, ${ }^{\star}$ C. R. Staples, ${ }^{*}$ T. C. Jenkins, $\dagger$ \\ and W. W. Thatcher ${ }^{\star 1}$ \\ *Department of Animal Sciences, University of Florida, Gainesville 32611 \\ †Department of Animal and Veterinary Sciences, Clemson University, SC 29634
}

\section{ABSTRACT}

The objectives were to evaluate the effects of differential timing of supplementation of different Ca salts (CS) of fatty acids (FA) on FA profiles of cotyledonarycaruncular tissues, metabolic status, uterine health, pregnancy, pregnancy losses after 2 artificial inseminations (AI), and milk yield. Holstein cows $(\mathrm{n}=1,380)$ were assigned randomly to be fed either CS of palm oil (PO) or safflower oil (SO) from $30 \mathrm{~d}$ prepartum until 30 d postpartum (dpp) and further randomized to receive either CS of PO or fish oil (FO) from 30 to 160 dpp. Supplementation of CS of FA was at $1.5 \%$ of dietary dry matter. Tissues $(\mathrm{n}=23)$ and blood $(\mathrm{n}=32)$ were collected from a subsample of cows. Blood was collected daily from parturition to $10 \mathrm{dpp}$ and three times weekly thereafter until $30 \mathrm{dpp}$ for analyses of $\mathrm{PGF}_{2 \alpha}$ metabolite, nonesterified FA, $\beta$-hydroxybutyric acid, blood urea nitrogen, and glucose. Cows were evaluated once between 8 to $10 \mathrm{dpp}$ for cervical discharge type. At 43 dpp, cows received 2 injections of $\mathrm{PGF}_{2 \alpha} 14 \mathrm{~d}$ apart, followed $14 \mathrm{~d}$ later by injections of $\mathrm{GnRH}$ at $7 \mathrm{~d}$ before and $56 \mathrm{~h}$ after an injection of $\mathrm{PGF}_{2 \alpha}$ with $\mathrm{AI}$ at $16 \mathrm{~h}$ after the second GnRH injection. All cows received intravaginally a controlled internal drug-releasing device, containing $1.38 \mathrm{~g}$ of progesterone, at $18 \mathrm{~d}$ after the first AI followed $7 \mathrm{~d}$ later by removal of the device and injection of GnRH. Nonpregnant cows at $32 \mathrm{~d}$ after AI were injected with $\mathrm{PGF}_{2 \alpha}$, followed $56 \mathrm{~h}$ later with a GnRH injection and second AI 16 h thereafter. Cows diagnosed pregnant after both AI were re-examined at $60 \mathrm{~d}$ of pregnancy to determine pregnancy losses. Milk weights were recorded monthly for all cows. Caruncular n-6:n-3 FA ratio was greater in cows fed SO. Plasma concentrations of metabolites and frequency of cervical discharge type did not differ between PO- and SO-fed

Received April 23, 2010

Accepted October 4, 2010.

${ }^{1}$ Corresponding author: thatcher@animal.ufl.edu cows. Plasma $\mathrm{PGF}_{2 \alpha}$ metabolite was greater in SO-fed cows at 4 and $7 \mathrm{dpp}$. Pregnancy per AI at 32 and $60 \mathrm{~d}$ post first AI was not affected by diets, but pregnancy loss was less in FO-fed cows. At second AI, pregnancy was greater in FO-fed cows at $32 \mathrm{~d}$ and in SO-FO-fed cows at $60 \mathrm{~d}$ post AI. Pregnancy loss after second AI was not affected by diets. Overall pregnancy per AI was greater in cows fed SO followed by FO at $60 \mathrm{~d}$ of pregnancy and pregnancy loss was reduced in FOfed cows. Monthly milk yield was greater $(0.7 \mathrm{~kg} / \mathrm{d})$ in SO-fed cows. In conclusion, strategic feeding of CS of FA during transition and breeding periods can benefit fertility and milk production of lactating dairy cows.

Key words: dairy cow, fatty acid, pregnancy, milk yield

\section{INTRODUCTION}

The transition period, typically considered from the last $3 \mathrm{wk}$ prepartum until $3 \mathrm{wk}$ postpartum, is marked by a decline in DMI, negative energy status once lactation is initiated (Staples et al., 1990), and inadequate innate immunity (Kimura et al., 1999, 2002; Weber et al., 2001; Hammon et al., 2006) that increases the risk of uterine diseases (Kimura et al., 2002; Hammon et al., 2006).

Prostaglandins are derived from the membrane phospholipid stores of arachidonic acid (C20:4n-6), which are synthesized from the essential dietary fatty acid linoleic acid (C18:2n-6). In the first $10 \mathrm{~d}$ postpartum, intense secretion of uterine $\mathrm{PGF}_{2 \alpha}$ occurs, evidenced by concentrations of plasma 13,14-dihydro-15-keto $\mathrm{PGF}_{2 \alpha}$ metabolite (PGFM) (Guilbault et al., 1984), which was elevated in cows that did not develop metritis (Seals et al., 2002; Silvestre et al., 2009). Indeed, $\mathrm{PGF}_{2 \alpha}$ has tonic effects on the uterus (Gajewski et al., 1999) and increases ex-vivo neutrophil activity (Hoedemaker et al., 1992). Prepartum pregnant ewes supplemented with a linoleic acid-enriched diet had increased proportions of arachidonic acid in the endometrium and 
allantochorion, and increased secretion of $\mathrm{PGF}_{2 \alpha}$ in cultured placental explants (Elmes et al., 2004). Moreover, prepartum cows (Cullens, 2005) and heifers (Juchem et al., 2010) supplemented with linoleic acid-enriched diets had increased concentrations of plasma PGFM after parturition.

Fatty acids of the n-3 family reduced pulsatile secretion of $\mathrm{PGF}_{2 \alpha}$ (Mattos et al., 2004) and improved pregnancy per AI (P/AI) in lactating dairy cows (Bruckental et al., 1989; Armstrong et al., 1990; Carroll et al., 1994; and Burke et al., 1997). Also, cows fed flaxseed, which is a source of $\alpha$-linolenic acid (C18:3n-3), had either increased P/AI (Petit et al., 2001), no effect (Ambrose et al., 2006; Fuentes et al., 2008), or reduced pregnancy loss from 30 to $50 \mathrm{~d}$ of pregnancy (Petit and Twagiramungu, 2006).

It was hypothesized that feeding calcium salts (CS) of linoleic acid (safflower oil) before parturition and during the first $30 \mathrm{~d}$ postpartum (dpp) would increase the percentages of linoleic and arachidonic acids in caruncular tissue, enhance synthesis of $\mathrm{PGF}_{2 \alpha}$, and improve uterine health. Furthermore, feeding CS of eicosapentaenoic acid (EPA) and docosahexaenoic acid (DHA; fish oil), beginning at $30 \mathrm{dpp}$, would increase $\mathrm{P} / \mathrm{AI}$ and reduce pregnancy losses. Therefore, our objectives were to determine the optimal fatty acid (FA) supplementation for the transition and breeding periods associated with metabolic status and uterine health, $\mathrm{P} / \mathrm{AI}$, pregnancy losses, and lactation performance in dairy cows.

\section{MATERIALS AND METHODS}

\section{Animals, Experimental Design, and Feeding}

The experiment was conducted at a north Florida dairy farm comprised of 3,500 Holstein cows that were milked three times daily. Cows were housed in free-stall barns during pre- and postpartum stages of the study.

Cows $(\mathrm{n}=1,582)$ were allocated randomly into 2 experimental transition diets begun at approximately $30 \mathrm{~d}$, and not less than $14 \mathrm{~d}$, before the expected date of parturition and continued until $30 \mathrm{dpp}$. Primiparous and multiparous cows were blocked when assigned to diets. After $30 \mathrm{dpp}$, cows within each transition diet were blocked by parity (i.e., primiparous and multiparous) and allocated randomly to the experimental breeding diets that were fed until $160 \mathrm{dpp}$ (Figure 1A). All cows were identified with colored ear tags according to assigned diet to ensure pen location. Experimental transition (Tables 1 and 2) and breeding (Table 2) diets differed only in the source of supplemental FA.

Transition diets were supplemented with CS of palm oil (PO; EnerGII) or CS of safflower oil (SO; Prequel
21), and breeding diets supplemented with CS of PO (EnerGII) or CS of fish oil (FO; StrataG). All CS of FA were manufactured by Virtus Nutrition, Corcoran, CA and supplemented at $1.5 \%$ of DM. The combinational experimental diets fed during the transition and breeding periods were $\mathrm{PO}-\mathrm{PO}, \mathrm{PO}-\mathrm{FO}$, SO-PO, and SO-FO, respectively (Figure 1A).

Diets were formulated to meet or exceed NRC (2001) nutrient requirements for $\mathrm{NE}_{\mathrm{L}}, \mathrm{CP}$, fiber, minerals, and vitamins (Tables 1 and 2) and fed to obtain an intake of 200 and $400 \mathrm{~g} / \mathrm{d}$ of CS of FA, for pre- and postpartum cows, respectively. Diets were fed as a TMR twice daily targeting 5\% orts. Group DM intakes were calculated daily based on the total feed offered minus that refused throughout the study.

All cows were evaluated once between 8 to $10 \mathrm{dpp}$ for cervical discharge using a disposable foil-lined cardboard vaginal speculum (Milburn Distributors, Ocala, FL). Appearance of discharge was categorized into lochia, clear mucus without flecks, clear mucus with flecks, mucopurulent (50\% clear mucus and approximately $50 \%$ of pus), and purulent ( $>50 \%$ pus to brown and foul smell).

Primiparous and multiparous cows were housed together during each pre- and postpartum (i.e., $30 \mathrm{dpp}$ ) periods. Pre- and postpartum experimental diets were offered to cows in separate free-stall pens that were located in common barns for each period. After 30 dpp primiparous and multiparous cows were located in separate barns that housed pens for the 2 experimental breeding diets. Cows that had been fed experimental diets for less than $14 \mathrm{~d}$ in the prepartum period or had dystocia requiring veterinary assistance (i.e., cesarian section, fetotomy) and gestation lengths less than $265 \mathrm{~d}$ were excluded from the experiment. Calving assistance score was recorded by the farm personnel into no assistance, minor assistance (use of hands with minor force), or major assistance (use of chain with intense force).

The free-stall pens within the barns used during the transition and breeding periods were identical in design, size, location, and orientation, and were equipped with one row of fans above the feed-bunk and others above the free-stalls. Moreover, at the time at which approximately one half of the total population of cows calved, the prepartum and postpartum experimental groups of cows (i.e., $\mathrm{PO}$ and $\mathrm{SO}$ ) with their respective transition diets interchanged pens by design within the pre- and postpartum free-stall barns. Also, at the time at which one half of the total population of cows reached approximately $90 \mathrm{dpp}$, cows with their respective breeding diets (i.e., PO and FO) interchanged pens, by design, within their free-stall barns. The interchange of pens allowed for the control of possible environmental housing bias in the study. Therefore, cows were considered as 
A

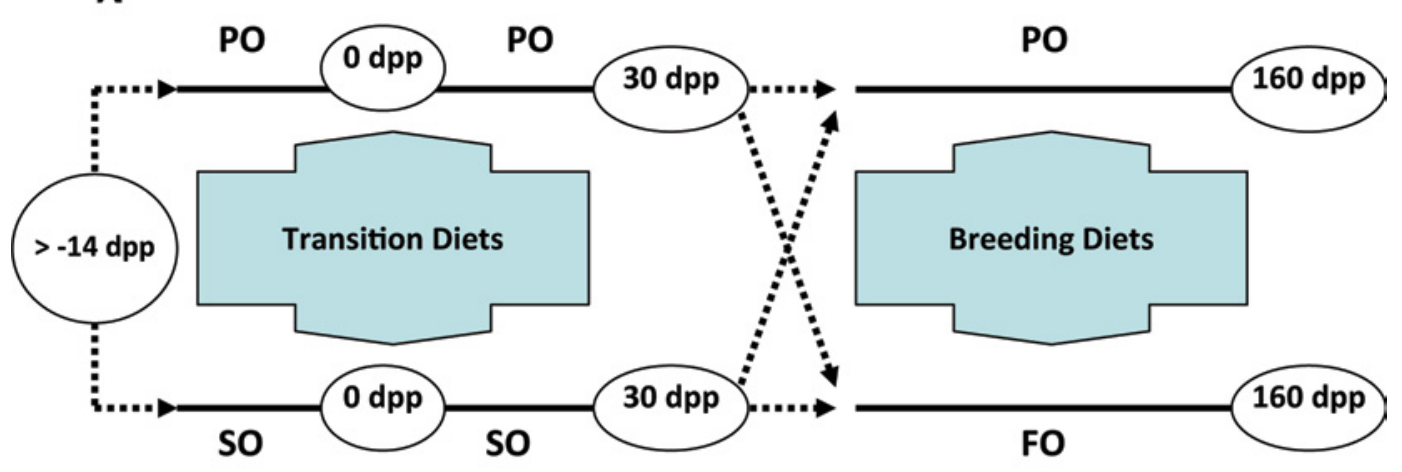

B
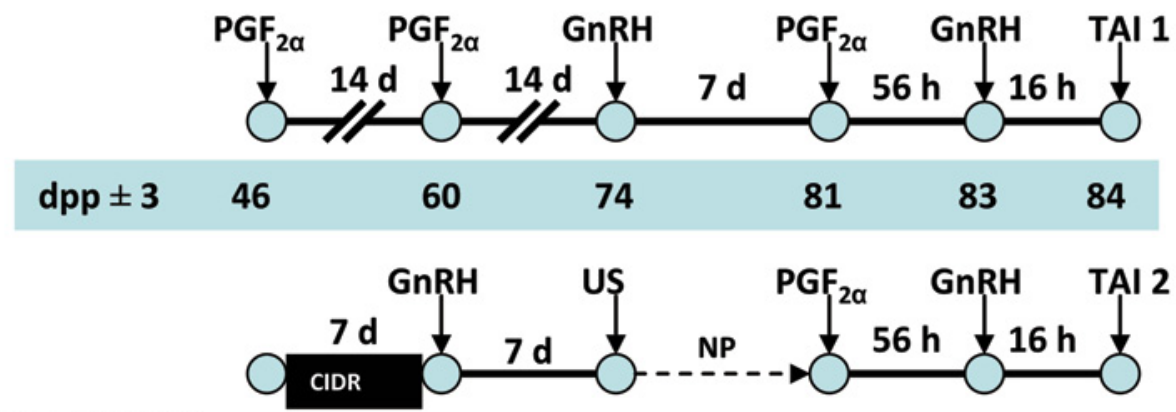

Days after TAI
18
25
32
32
34
35

Figure 1. Diagram of experimental design (A) and breeding program for first and second services (B). Transition diets were supplemented with calcium salts (CS) of palm oil (PO) or CS of safflower oil (SO) from at least $14 \mathrm{~d}$ prepartum until $30 \mathrm{~d}$ postpartum (dpp), and breeding diets were supplemented with CS of PO or CS of fish oil (FO) from 30 to $160 \mathrm{dpp}$. All CS of fatty acids were supplemented at $1.5 \%$ of dry matter. TAI = timed artificial insemination; CIDR $=$ controlled internal drug release containing $1.38 \mathrm{~g}$ of progesterone; US = ultrasonography; NP $=$ nonpregnant. Color version available in the online PDF.

the experimental units to provide statistical power to test the hypothesis that nutritional intervention could affect establishment and maintenance of pregnancy.

Daily temperature $\left({ }^{\circ} \mathrm{C}\right)$ and relative humidity (\%) data were obtained from the Florida Automated Weather Network (http://fawn.ifas.ufl.edu/scripts/reportrequest.asp) from November 2006 to August 2007. The weather station is located in Alachua, Florida, approximately $70 \mathrm{~km}$ from the experimental location. Average daily temperature was converted from Celsius to Fahrenheit $\left({ }^{\circ} \mathrm{F}\right)$, using the equation ${ }^{\circ} \mathrm{F}=\left({ }^{\circ} \mathrm{C} \times 9 / 5\right)$ +32 and used to calculate the average daily temperature-humidity index $(\mathbf{T H I})$ as: $\mathrm{THI}=\mathrm{td}-(0.55-0.55$ $\mathrm{RH} / 100)$ ( $\mathrm{td}-58)$, where $\mathrm{td}$ is the average dry bulb temperature in ${ }^{\circ} \mathrm{F}$, and $\mathrm{RH}$ is the average daily relative humidity expressed as a percentage (NOAA, 1976). Seasons were defined as cool (THI $<72$ ) and warm (THI 272) (Johnson, 1976; West, 2003).

\section{Placentome Collection}

A sub-sample of cows $(\mathrm{PO}=11$ and $\mathrm{SO}=12)$ was used for collection of cotyledonary-caruncular tissue. Only cows fed the prepartum diets for more than 20 $\mathrm{d}$ were included. Cotyledonary-caruncular units (placentome) were extracted manually through the vagina using a shoulder-length sleeve. The perineal area was washed with povidone-iodine scrub $(0.75 \%$ titratable iodine and $1 \%$ povidone solution; Agripharm, Memphis, $\mathrm{TN}$ ) and dried before collection. Collection was within 7 $\mathrm{h}$ after parturition (average of $3 \mathrm{~h}$ ) and before placental expulsion. None of the cows developed a retained placenta. After collection, caruncles and cotyledons were separated manually, washed with water, put into respective plastic bags, each plunged into liquid nitrogen and stored at $-80^{\circ} \mathrm{C}$. Tissues were then freeze-dried for $72 \mathrm{~h}$ and analyzed for FA composition (Jenkins, 2010). 
Table 1. Ingredients and chemical composition of diets fed to prepartum cows

\begin{tabular}{|c|c|c|c|}
\hline \multirow[b]{2}{*}{ Item } & \multirow[b]{2}{*}{$\%$ of DM } & \multicolumn{2}{|c|}{ Fat supplement $^{1}$} \\
\hline & & $\mathrm{PO}$ & $\mathrm{SO}$ \\
\hline \multicolumn{4}{|l|}{ Ingredient } \\
\hline Corn silage & 26.7 & & \\
\hline Ryegrass silage & 6.7 & & \\
\hline Sorghum silage & 13.3 & & \\
\hline Alfalfa hay & 3 & & \\
\hline Rye hay & 6 & & \\
\hline Cottonseed hulls & 15 & & \\
\hline Brewers grains, wet & 3.3 & & \\
\hline Soybean meal & 3 & & \\
\hline Soy Plus ${ }^{2}$ & 9.5 & & \\
\hline Corn grain, ground & 7.9 & & \\
\hline Mineral and vitamin mix & 2.2 & & \\
\hline Bovachlor $^{3}$ & 2 & & \\
\hline Fat supplement & 1.5 & & \\
\hline Total & 100 & & \\
\hline \multicolumn{4}{|l|}{ Chemical composition } \\
\hline $\mathrm{NE}_{\mathrm{L}}(\mathrm{Mcal} / \mathrm{kg}$ of DM $)$ & & 1.43 & 1.45 \\
\hline $\mathrm{CP}(\%$ of $\mathrm{DM})$ & & 13.2 & 13.8 \\
\hline Fat (\% of DM) & & 3.7 & 3.7 \\
\hline $\mathrm{NDF}(\%$ of DM) & & 49.5 & 52.8 \\
\hline $\mathrm{ADF}(\%$ of $\mathrm{DM})$ & & 33.2 & 34.7 \\
\hline $\mathrm{Ca}(\%$ of $\mathrm{DM})$ & & 0.89 & 0.87 \\
\hline $\mathrm{P}(\%$ of $\mathrm{DM})$ & & 0.33 & 0.32 \\
\hline $\mathrm{K}(\%$ of $\mathrm{DM})$ & & 1.31 & 1.32 \\
\hline $\mathrm{Mg}(\%$ of $\mathrm{DM})$ & & 0.29 & 0.29 \\
\hline $\mathrm{Na}(\%$ of $\mathrm{DM})$ & & 0.2 & 0.2 \\
\hline $\mathrm{Cl}(\%$ of $\mathrm{DM})$ & & 1.21 & 1.45 \\
\hline $\mathrm{S}(\%$ of $\mathrm{DM})$ & & 0.19 & 0.19 \\
\hline $\mathrm{Mn}(\mathrm{mg} / \mathrm{kg}$ of DM) & & 79 & 68 \\
\hline $\mathrm{Cu}(\mathrm{mg} / \mathrm{kg}$ of $\mathrm{DM})$ & & 24 & 21 \\
\hline $\mathrm{Zn}(\mathrm{mg} / \mathrm{kg}$ of DM) & & 85 & 80 \\
\hline $\mathrm{Fe}(\mathrm{mg} / \mathrm{kg}$ of $\mathrm{DM})$ & & 283 & 260 \\
\hline
\end{tabular}

${ }^{1} \mathrm{PO}$ (palm oil; EnerGII) or SO (safflower oil; Prequel 21). All fat supplements were manufactured as Ca salts by Virtus Nutrition, LLC, Corcoran, CA.

${ }^{2}$ West Central Soy, Ralston, IA.

${ }^{3}$ On a DM basis: $60 \%$ CP, $22.2 \%$ sugar, $0.44 \%$ Ca, $0.66 \% \mathrm{Mg}, 2.22 \%$ K, $2.22 \% \mathrm{Na}, 0.44 \% \mathrm{~S}$, and $24.4 \% \mathrm{Cl}$, (Westway Feed Prod., Tomball, TX).

\section{Estrous Synchronization and Resynchronization}

Cows, beginning at $43 \mathrm{dpp}$, were enrolled once weekly into a Presynch protocol with 2 injections of $\mathrm{PGF}_{2 \alpha}(25$ $\mathrm{mg}$, dinoprost tromethamine, i.m., Lutalyse; Sterile Solution; Pfizer Animal Health, New York, NY) injected $14 \mathrm{~d}$ apart. The Ovsynch protocol was initiated $14 \mathrm{~d}$ after the second $\mathrm{PGF}_{2 \alpha}$ injection of the Presynch with a GnRH injection $(100 \mu \mathrm{g}$; gonadorelin diacetate tetrahydrate, i.m., Cystorelin, Merial Ltd., Athens, GA), followed $7 \mathrm{~d}$ later by an injection of $\mathrm{PGF}_{2 \alpha}$ and a final GnRH injection $56 \mathrm{~h}$ later. Timed artificial insemination (TAI) was performed $16 \mathrm{~h}$ after the last $\mathrm{GnRH}$ injection of the Ovsynch protocol (Figure 1B).

All cows received a controlled internal drug-releasing device (CIDR, Eazi-Breed; Pfizer Animal Health, New York, NY), containing $1.38 \mathrm{~g}$ of progesterone, at $18 \mathrm{~d}$ after the first TAI, followed $7 \mathrm{~d}$ later by removal of the
CIDR device and an injection of $100 \mu \mathrm{g}$ of $\mathrm{GnRH}$. At $32 \mathrm{~d}$ after the first TAI, cows were examined by per-rectum ultrasonography to identify presence of an embryo and an embryonic heart beat. Nonpregnant cows were injected with $25 \mathrm{mg}$ of $\mathrm{PGF}_{2 \alpha}$ and then injected with $100 \mu \mathrm{g}$ of GnRH $56 \mathrm{~h}$ later. A TAI was performed $16 \mathrm{~h}$ after the last $\mathrm{GnRH}$ injection for the second insemination (Figure 1B). Cows were examined by per-rectum ultrasonography $32 \mathrm{~d}$ after the second TAI. All cows diagnosed pregnant after first and second services were re-examined by per-rectum ultrasonography at $60 \mathrm{~d}$ after insemination to determine pregnancy losses. Artificial inseminations were conducted randomly within diets by 4 technicians.

\section{Blood Samples and Progesterone Assay}

Blood samples were collected from all cows before the second injection of $\mathrm{PGF}_{2 \alpha}$ of the Presynch and at the time of the first $\mathrm{GnRH}$ injection of the Ovsynch protocol for the first TAI. Blood samples were collected by puncture of coccygeal vessels into evacuated tubes containing $\mathrm{K}_{2}$-EDTA (Vacutainer, BD, Franklin Lakes, NJ). Samples were placed immediately into an ice bath until centrifugation for $20 \mathrm{~min}$ at $2,619 \times \mathrm{g}$. After centrifugation, plasma was harvested and stored frozen at $-20^{\circ} \mathrm{C}$ until assayed. With this set of blood samples, cows were considered to have initiated estrous cycles if plasma concentration of progesterone $\left(\mathbf{P}_{4}\right)$ was greater than $1 \mathrm{ng} / \mathrm{mL}$ in at least 1 of the 2 samples (cyclic), or non-cyclic or anovulatory if both samples were below 1 $\mathrm{ng} / \mathrm{mL}$. Concentrations of plasma $\mathrm{P}_{4}$ were determined by radioimmunoassay using a Coat-A-Count Kit (DPC Diagnostic Products Incorporation, Los Angeles, CA) designed for the quantitative measurement of $\mathrm{P}_{4}$ in plasma. Duplicated reference samples for plasma $\mathrm{P}_{4}$ were low $(<1.0 \mathrm{ng} / \mathrm{mL})$, medium $(\geq 1.0$ and $<3.0 \mathrm{ng} /$ $\mathrm{mL})$ and high $(\geq 3.0 \mathrm{ng} / \mathrm{mL})$. Intraassay coefficients of variation of low, medium, and high samples were 4.1, 4.7 , and $6.0 \%$, respectively. Interassay coefficients of variation were $6.1,7.2$, and $10.4 \%$, respectively. Sensitivity of the assay was $0.1 \mathrm{ng} / \mathrm{mL}$.

\section{Body Condition Score}

All experimental cows were evaluated for BCS at the day of enrollment, at parturition, at $43 \mathrm{dpp}$, and at the first TAI. Scores were given by 2 veterinarians based on a 1 (thin) to 5 (obese) scale using a quarter point system (Edmonson et al., 1989). Changes in BCS were obtained by subtracting BCS at parturition from BCS at enrollment, BCS at $43 \mathrm{dpp}$ from BCS at parturition, and BCS at TAI from BCS at $43 \mathrm{dpp}$. The BCS gain or loss was used as an indicator of energy status. 
Table 2. Ingredients and chemical composition of diets fed to lactating cows ${ }^{1}$

\begin{tabular}{|c|c|c|c|c|c|c|}
\hline \multirow[b]{2}{*}{ Item } & \multicolumn{2}{|c|}{$\%$ of $\mathrm{DM}$} & \multicolumn{2}{|c|}{ Postpartum $^{2}$} & \multicolumn{2}{|c|}{ Breeding $^{3}$} \\
\hline & Postpartum & Breeding & $\mathrm{PO}$ & $\mathrm{SO}$ & $\mathrm{PO}$ & FO \\
\hline \multicolumn{7}{|l|}{ Ingredient } \\
\hline Corn silage & 28.1 & 33.6 & & & & \\
\hline Ryegrass silage & 22.4 & 11.2 & & & & \\
\hline Cottonseed hulls & 2.6 & 3.8 & & & & \\
\hline Liquid blend $^{4}$ & 0.9 & 1.1 & & & & \\
\hline Cottonseed, whole & 2.6 & 33 & & & & \\
\hline Brewers grains, wet & 2.2 & 5.5 & & & & \\
\hline Soybean meal & 5 & 6.1 & & & & \\
\hline Soy Plus ${ }^{5}$ & 10.7 & 5.1 & & & & \\
\hline Citrus pulp & 3.3 & 4 & & & & \\
\hline Corn grain, ground & 18 & 21.3 & & & & \\
\hline Promix & 2.7 & 3.5 & & & & \\
\hline Fat supplement & 1.5 & 1.5 & & & & \\
\hline \multicolumn{7}{|l|}{ Chemical composition } \\
\hline $\mathrm{NE}_{\mathrm{L}}(\mathrm{Mcal} / \mathrm{kg}$ of DM) & & & 1.54 & 1.6 & 1.67 & 1.63 \\
\hline $\mathrm{CP}(\%$ of $\mathrm{DM})$ & & & 15.7 & 16 & 16.8 & 16.3 \\
\hline Fat (\% of DM) & & & 4.3 & 4.5 & 5.1 & 4.6 \\
\hline $\mathrm{NDF}(\%$ of DM) & & & 38.6 & 38.8 & 34.2 & 34.8 \\
\hline $\mathrm{ADF}(\%$ of $\mathrm{DM})$ & & & 25 & 23 & 22.2 & 21.9 \\
\hline $\mathrm{Ca}(\%$ of $\mathrm{DM})$ & & & 0.78 & 0.75 & 0.81 & 0.88 \\
\hline $\mathrm{P}(\%$ of $\mathrm{DM})$ & & & 0.38 & 0.39 & 0.39 & 0.39 \\
\hline $\mathrm{K}(\%$ of $\mathrm{DM})$ & & & 1.37 & 1.4 & 1.2 & 1.2 \\
\hline $\mathrm{Mg}(\%$ of $\mathrm{DM})$ & & & 0.25 & 0.25 & 0.24 & 0.25 \\
\hline $\mathrm{Na}(\%$ of $\mathrm{DM})$ & & & 0.23 & 0.22 & 0.25 & 0.27 \\
\hline $\mathrm{Cl}(\%$ of $\mathrm{DM})$ & & & 0.57 & 0.4 & 0.51 & 0.55 \\
\hline $\mathrm{S}(\%$ of $\mathrm{DM})$ & & & 0.22 & 0.22 & 0.24 & 0.24 \\
\hline $\mathrm{Mn}(\mathrm{mg} / \mathrm{kg}$ of $\mathrm{DM})$ & & & 69 & 66 & 66 & 70 \\
\hline $\mathrm{Cu}(\mathrm{mg} / \mathrm{kg}$ of $\mathrm{DM})$ & & & 16 & 16 & 17 & 19 \\
\hline $\mathrm{Zn}(\mathrm{mg} / \mathrm{kg}$ of $\mathrm{DM})$ & & & 70 & 71 & 76 & 81 \\
\hline $\mathrm{Fe}(\mathrm{mg} / \mathrm{kg}$ of $\mathrm{DM})$ & & & 179 & 211 & 214 & 181 \\
\hline
\end{tabular}

${ }^{1}$ Diets contained one of the following fat supplements: PO (palm oil; EnerGII), SO (safflower oil; Prequel 21), or FO (fish oil; StrataG). All fat supplements were manufactured as Ca salts by Virtus Nutrition, LLC, Corcoran, CA.

${ }^{2}$ Diet fed from parturition to $30 \mathrm{~d}$ postpartum.

${ }^{3}$ Diet fed from 30 to $160 \mathrm{~d}$ postpartum.

${ }^{4}$ Blend of molasses, glycerin, and corn steep liquor.

${ }^{5}$ West Central Soy, Ralston, IA.

\section{Milk Yield and Feed Samples}

Milk weights were recorded once a month for each cow for 5 mo. First measurements occurred at different times after parturition for the first monthly sample depending upon the day of parturition in relation to the day of the monthly milk test for the herd. Because cows were assigned to the treatments randomly on a weekly basis, the day of the first postpartum measurement was balanced between treatments. The single measurement of milk production for each month was considered as the average for the month. Data from the first $5 \mathrm{mo}$ of lactation were used.

Total mixed rations were sampled weekly at the time of feeding from respective feed-bunks and immediately frozen in plastic bags. Samples were thawed, composited (i.e., 4 samples/month), freeze-dried, further composited into a 3-mo sample, and analyzed by wet chemistry methods for chemical (Dairy One, Ithaca, NY) and FA composition (Jenkins, 2010).

\section{PGFM and Blood Metabolites}

A subsample of cows $(\mathrm{PO}=15$ and $\mathrm{SO}=17)$ was used for blood sampling during the postpartum period. Blood samples were collected and processed as described above for progesterone measurements. Samples were collected once daily from parturition to $10 \mathrm{dpp}$ for measurement of plasma PGFM concentrations as an index of uterine $\mathrm{PGF}_{2 \alpha}$ secretion. Plasma samples were analyzed for concentrations of PGFM using a radioimmunoassay procedure described by Mattos et al. (2004). Inter- and intraassay coefficients of variation for one reference sample $(1.43 \mathrm{ng} / \mathrm{mL})$ were 3.65 and $4.15 \%$, respectively. Inter- and intraassay coefficients of variation for a second reference sample $(3.2 \mathrm{ng} / \mathrm{mL})$ 
were 4.38 and $6.65 \%$, respectively. Sensitivity of the assay was $0.03 \mathrm{ng} / \mathrm{mL}$.

Blood from coccygeal vessels was collected three times weekly from the same sub-sample of cows between 10 and 35 dpp for analyses of plasma concentrations of NEFA (Wako Diagnostics, Richmond, VA), as modified by Johnson and Peters (1993), and BHBA (Wako Diagnostics). In addition, a Technicon Autoanalyzer (Technicon Instruments Corp., Chauncey, NY) was used to determine concentrations of BUN following a modification of Coulombe and Favreau (1963), as described in Bran + Luebbe Industrial Method \#339-01, and plasma glucose following a modification of Gochman and Schmitz (1972) as described in Bran + Luebbe Industrial Method \#339-19.

\section{Statistical Analyses}

Milk yield, proportion of cyclic cows, P/AI, pregnancy losses, and cumulative proportion of pregnant cows after 2 TAI were analyzed using pre-determined statistical contrasts to test the effects of the transition diets (PO-PO + PO-FO vs. SO-PO + SO-FO), breeding diets $(\mathrm{PO}-\mathrm{PO}+\mathrm{SO}-\mathrm{PO}$ vs. $\mathrm{PO}-\mathrm{FO}+\mathrm{SO}-\mathrm{FO})$ and the interaction of transition and breeding diets (PO-PO $+\mathrm{SO}-\mathrm{FO}$ vs. $\mathrm{PO}-\mathrm{FO}+\mathrm{SO}-\mathrm{PO}$ ).

Proportion of cyclic cows, $\mathrm{P} / \mathrm{AI}$, pregnancy losses, and cumulative proportion of pregnant cows after 2 TAI were analyzed by logistic regression (SAS Institute Inc., Cary, NC). The logistic regression stepwise selection procedure was used for all independent variables and possible interactions with pre-determined significance levels set for a variable to be entered with a $P$ $\leq 0.30$ and retained with $P \leq 0.20$ in the model. The mathematical model for cyclic responses included diet, parity, calving assistance, cervical discharge score, 5-mo accumulated milk weight, BCS, changes in BCS, and all higher order interactions. The mathematical model for pregnancy responses included diet, parity, calving assistance, cervical discharge score, cyclic status (cyclic or noncyclic), inseminator, sire, season (i.e., THI $<72$ or $\geq 72$ ), accumulated milk weight, BCS, changes in BCS, and all higher order interactions. Accumulated milk weight and BCS data were categorized into quartiles using the Univariate procedure of SAS. After identifying variables that were significant, the model was reduced and analyzed using the generalized linear model (GENMOD) of SAS with a binomial distribution and a logit link function to obtain odds ratios, confidence intervals, and probability values.

Milk yield data for the first 5 mo were analyzed using the repeated measures analyses of the mixed model of SAS. Covariance structures tested included compound symmetry, autoregressive 1, and unstructured. Autore- gressive 1 had the best relative goodness of fit based upon penalty criteria (Bayesian criterion). The statistical model consisted of diet, parity, month postpartum, BCS (i.e., at enrollment, parturition, $43 \mathrm{dpp}$, and at TAI), and higher order interactions. Cow, the random variable, was considered as the experimental unit nested within diet and parity.

The GENMOD procedure of SAS was used to analyze cervical discharge scores with a multinomial distribution of response and a logit link function. The mathematical model included diet (i.e., PO and SO), parity, diet by parity interaction, calving assistance, retained fetal membranes (i.e., yes or no), and BCS (enrollment and parturition). Binomially distributed health data (i.e., mastitis, ketosis, lameness, and displacement of abomasum) obtained from farm records were analyzed in GENMOD procedure of SAS with a binomial distribution and a logit link function.

Plasma concentrations of PGFM and blood metabolites (i.e., BHBA, NEFA, BUN, and glucose) were analyzed using repeated measures responses of the mixed model procedure of SAS. Data were tested for normal distribution of the residuals by the PROC UNIVARIATE procedure of SAS. Residuals were considered to be normally distributed when the Shapiro-Wilk statistic was equal to or greater than 0.90 , and log-transformed if required. For each dependent variable, the autoregressive 1 covariance structure was selected because it had the best relative goodness of fit based upon penalty criteria (Bayesian criterion). The mathematical model contained diet (PO and $\mathrm{SO}$ ), day, and diet by day interaction. The random variable was cow nested within diet and parity.

\section{RESULTS}

\section{Animals, Diets, DMI, BCS, Vaginoscopy}

A total of 1,582 cows $(\mathrm{PO}, \mathrm{n}=800 ; \mathrm{SO}, \mathrm{n}=782)$ were enrolled and calved during the period of November 2006 to February 2007. A total of 202 cows (PO: $14.8 \%, 119 / 800$; SO: $10.6 \%, 83 / 782)$ were excluded at parturition because the length of prepartum feeding was less than $14 \mathrm{~d}$. Therefore, 1,380 cows (primiparous, $\mathrm{n}=460$; multiparous, $\mathrm{n}=920)$ remained in the experiment. Length of prepartum feeding was shorter $(P<$ $0.05)$ for primiparous $(26.9 \pm 0.5 \mathrm{~d})$ than multiparous $(28.2 \pm 0.4 \mathrm{~d})$ cows and did not differ between cows fed the 2 transition diets. Of the 1,380 parturitions, 1,092 cows had breeding records for calculation of gestation length. Gestation lengths were longer $(P<0.01)$ for primiparous $(288.3 \pm 1.5 \mathrm{~d})$ compared with those for multiparous $(280.7 \pm 1.0 \mathrm{~d})$ cows but were not affected by transition diets. Parturitions throughout the experi- 
Table 3. Fatty acid (FA) profiles of fat supplements

\begin{tabular}{lrrr}
\hline & \multicolumn{3}{c}{ Fat supplement $^{1}(\mathrm{~g} / 100 \mathrm{~g}$ of FA) } \\
\cline { 2 - 4 } Fatty acid & \multicolumn{1}{c}{ PO } & SO & FO \\
\hline C14:0 & 1.2 & 1.0 & 4.5 \\
C16:0 & 46.6 & 12.9 & 38.7 \\
C16:1 & 0.0 & 0.1 & 0.0 \\
C17:0 & 0.1 & 0.1 & 0.3 \\
C18:0 & 4.3 & 4.2 & 4.6 \\
C18:1 cis-9 & 38.2 & 16.7 & 30.8 \\
C18:2 n-6 & 9.3 & 63.6 & 8.0 \\
C18:3 n-3 & 0.3 & 0.2 & 1.0 \\
C20:4 n-6 & 0.0 & 0.0 & 0.4 \\
C20:5 n-3 & 0.0 & 0.6 & 5.4 \\
C22:5 n-3 & 0.0 & 0.1 & 0.9 \\
C22:6 n-3 & 0.0 & 0.4 & 5.3 \\
n-6/n-3 & 31.0 & 48.9 & 0.7 \\
\hline
\end{tabular}

${ }^{1} \mathrm{PO}$ (palm oil; EnerGII); SO (safflower oil; Prequel 21); FO (fish oil; StrataG). All fat supplements were manufactured as Ca salts by Virtus Nutrition, LLC, Corcoran, CA.

mental period occurred at the same monthly rate for cows fed the experimental transition diets. Of the 1,380 experimental cows, 297 cows were moved inadvertently out of experimental lots, missed injections or pregnancy diagnosis of breeding protocols, or exited study because of culling or death.

Chemical compositions of prepartum, postpartum, and breeding diets were similar when comparing the 2 dietary treatments (Tables 1 and 2). The n-6:n-3 FA ratio was greatest for $\mathrm{SO}(48.9)$, intermediate for $\mathrm{PO}$ (31.0), and lowest for FO $(<1)$ supplements (Table 3 ). The greater n-6:n-3 ratio of the SO supplement was because of the greater quantities of linoleic acid in this supplement $(63.6 \%)$. The low n-6:n-3 ratio in the FO supplement was because of the greater concentrations of EPA (5.4\%) and DHA (5.3\%) compared with those of the other FA supplements. Fatty acid compositions of the TMR (Table 4) were characterized by greater proportions of linoleic acid and EPA and DHA in diets supplemented with $\mathrm{SO}$ and FO, respectively.

Mean group DMI for cows fed SO were 14.4 and 19.0 $\mathrm{kg} / \mathrm{d}$, whereas cows fed PO were 13.5 and $17.6 \mathrm{~kg} / \mathrm{d}$ at pre- and postpartum stages, respectively. During the breeding period, mean group DMI for cows fed PO was $23.8 \mathrm{~kg} / \mathrm{d}$, whereas that for cows fed FO was 22.2 $\mathrm{kg} / \mathrm{d}$.

The frequency distribution of cows among different BCS quartiles did not differ at the time of initiation of transition diets prepartum (median BCS 3.25) and was not affected by transition diets at parturition (median BCS 3.0) and at 43 dpp (median BCS 2.75). Furthermore, the proportion of cows that lost, maintained, or gained BCS did not differ between cows fed the transition diets. When examining the distribution of cows among BCS quartiles (i.e., quartiles: $1=2.25$ to $2.5 \mathrm{BCS} ; 2=2.75 \mathrm{BCS} ; 3.0=3.0 \mathrm{BCS} ; 4=3.25$ to $3.75 \mathrm{BCS})$ at the first timed $\mathrm{AI}$, a greater $(P<$ 0.01) proportion of FO-fed cows were in the high BCS quartile category than cows fed the PO breeding diet (i.e., $17.7 \%>12.7 \%$ ). Indeed, a greater proportion of FO-fed cows gained body condition from $43 \mathrm{dpp}$ to TAI (11\% lost 0.75 to $0.25 ; 47 \%$ maintained; $42 \%$ gained 0.25 to 1.0$)$ than did PO-fed cows (16\% lost 0.75 to $0.25 ; 47 \%$ maintained; $37 \%$ gained 0.25 to 1.0$)$.

The frequency distribution of cows among calving assistance categories was not affected by diets or by BCS at enrollment and parturition. At parturition, a greater $(P<0.01)$ proportion of primiparous $(\mathrm{n}=344)$ than multiparous $(\mathrm{n}=759)$ cows had minor assistance (18.9 vs. $10 \%)$ and major assistance (22.7 vs. $5.7 \%)$, respectively.

Table 4. Fatty acid (FA) profiles of $\operatorname{diets}^{1}$

\begin{tabular}{|c|c|c|c|c|c|c|}
\hline \multirow[b]{2}{*}{ Fatty acid } & \multicolumn{2}{|c|}{ Prepartum $^{2}(\mathrm{~g} / 100 \mathrm{~g}$ of FA) } & \multicolumn{2}{|c|}{ Postpartum $^{3}(\mathrm{~g} / 100 \mathrm{~g}$ of FA) } & \multicolumn{2}{|c|}{ Breeding $^{4}(\mathrm{~g} / 100 \mathrm{~g}$ of FA) } \\
\hline & $\mathrm{PO}$ & SO & $\mathrm{PO}$ & $\mathrm{SO}$ & PO & FO \\
\hline C16:0 & 28.11 & 19.61 & 27.34 & 16.55 & 27.76 & 24.52 \\
\hline C18:0 & 3.54 & 3.30 & 3.51 & 3.24 & 3.47 & 3.61 \\
\hline C18:1 cis-9 & 23.59 & 18.32 & 23.50 & 17.76 & 23.52 & 21.62 \\
\hline C18:2 n-6 & 37.91 & 50.28 & 37.24 & 53.04 & 37.82 & 40.74 \\
\hline C22:5 n-3 & 0.0 & 0.0 & 0.0 & 0.0 & 0.0 & 0.22 \\
\hline C22:6 n-3 & 0.0 & 0.0 & 0.0 & 0.0 & 0.0 & 0.92 \\
\hline n-6/n-3 & 6.15 & 6.41 & 4.79 & 5.95 & 5.60 & 5.07 \\
\hline
\end{tabular}

${ }^{1}$ Diets contained one of the following fat supplements: PO (palm oil; EnerGII), SO (safflower oil; Prequel 21), or FO (fish oil; StrataG). All fat supplements were manufactured as Ca salts by Virtus Nutrition, LLC, Corcoran, CA.

${ }^{2}$ Diet fed for at least $14 \mathrm{~d}$ before parturition.

${ }^{3}$ Diet fed from parturition to $30 \mathrm{~d}$ postpartum.

${ }^{4}$ Diet fed from 30 to 160 d postpartum. 
Table 5. Frequency distribution of cows (\% and number of cows) among cervical discharge categories diagnosed between d 8 to 10 postpartum

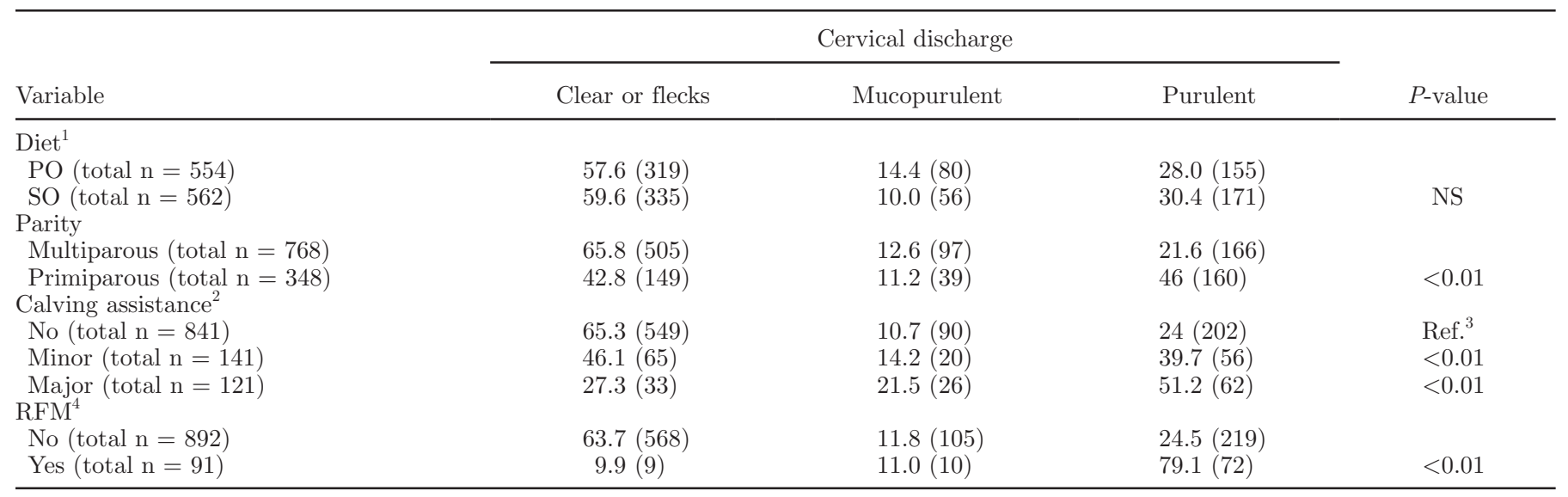

${ }^{1}$ PO (palm oil; EnerGII); SO (safflower oil; Prequel 21). All fat supplements were manufactured as Ca salts by Virtus Nutrition, LLC, Corcoran, CA.

${ }^{2}$ Calving assistance: No = no assistance; Minor = use of minor force; Major = use of a jack with minor or major force.

${ }^{3}$ Referent category.

${ }^{4}$ Retained fetal membranes.

Frequency distribution of cows among cervical discharge categories examined at 8 dpp (Table 5) was not affected by transition diets; however, primiparous cows, calving assistance, and retained fetal membrane were variables associated with a greater $(P<0.01)$ proportion of purulent cervical discharge (Table 5).

\section{Fatty Acid Profiles in Cotyledonary and Caruncular Tissues}

The subsample of cows used for tissue collection was fed during the prepartum period for $33 \pm 9 \mathrm{~d}$. Caruncular content of linoleic acid tended to be greater $(P$ $<0.10)$ in SO-fed cows compared with that of PO-fed cows (Table 6). Additionally, caruncular and cotyledonary contents of palmitic acid $(16: 0)$ were less $(P<0.01)$ in cows supplemented with SO compared with those in cows supplemented with PO (Table 6). Total FA content was less $(P<0.01)$ in fetal cotyledonary tissue than in maternal caruncular tissue ( 4.5 vs. $8.6 \mathrm{~g} / 100 \mathrm{~g}$ of tissue, respectively; Table 7). The predominant FA in the cotyledon and caruncle was oleic acid (C18:1 cis-9; 24.5\%) and stearic acid (C18:0; 20.8\%), respectively. Saturated FA content was less $(P<0.01)$ in the cotyledon than in the caruncle, which was associated with a greater $(P<0.01)$ content of unsaturated $\mathrm{FA}$ in the cotyledonary tissue (Table 7 ). The cotyledon had a lower $(P<0.01)$ content of myristic acid $(\mathrm{C} 14: 0)$ and stearic acid, and a greater $(P<0.01)$ content of oleic acid, C18:1 cis-11, conjugated linoleic acid (CLA) trans-9, trans-11, and DHA. Moreover, the linoleic acid content of caruncles was greater $(P<0.01)$ compared with that of the cotyledon. Consequently, the n-6:n-3 ratio was greater $(P<0.01)$ in the caruncle (Table 7 ).

\section{PGFM and Blood Metabolites}

Blood sampling during the postpartum period was terminated in 10 cows of each diet because of treatments with antibiotics and anti-inflammatory drugs. Therefore, 15 PO- and 17 SO-fed cows were used for analyses of concentration of PGFM and blood metabolites in plasma. The subset of cows sampled were fed the SO diet for a longer $(P<0.01)$ period of time $(34.8$ $\pm 1.4 \mathrm{~d})$ compared with those fed PO $(30.8 \pm 1.3 \mathrm{~d})$ in the prepartum period. The proportion of cows in BCS categories at the day of enrollment did not differ between diets. All cows had a normal parturition (i.e., no assistance), except for one cow requiring minor assistance. A total of $10,2,1$, and 2 cows in the PO treatment and 9,5,0, and 3 cows in the SO treatment were diagnosed with either clear or normal lochia, flecks, mucupulent, or purulent cervical discharge, respectively, at $8 \mathrm{dpp}$, and were not treated with antibiotics or anti-inflammatory drugs.

Plasma concentrations of PGFM were not affected by transition diets (Figure 2) except at d 4 and 7 postpartum, when a greater $(P<0.05)$ concentration was detected for cows fed SO $(2.80 \pm 0.31$ and $2.66 \pm 0.31$ $\mathrm{ng} / \mathrm{mL})$ than those fed PO $(2.08 \pm 0.32$ and $1.44 \pm 0.32$ $\mathrm{ng} / \mathrm{mL}$ ) diets, respectively. Mean plasma concentration of NEFA $(316 \pm 38$ and $372 \pm 37 \mu \mathrm{M})$, BHBA $(5.5 \pm$ 0.4 and $5.3 \pm 0.4 \mathrm{mg} / 100 \mathrm{~mL})$, BUN $(21.9 \pm 5.5$ and $19.3 \pm 5.4 \mathrm{mg} / 100 \mathrm{~mL})$, and glucose $(55.9 \pm 5.4$ and 
Table 6. Least squares means and pooled SE of fatty acid profiles (\% of the total fatty acid; g/100 g of fatty acid) of cotyledonary and caruncular tissues collected at the time of parturition from cows supplemented with palm oil or safflower oil ${ }^{1}$

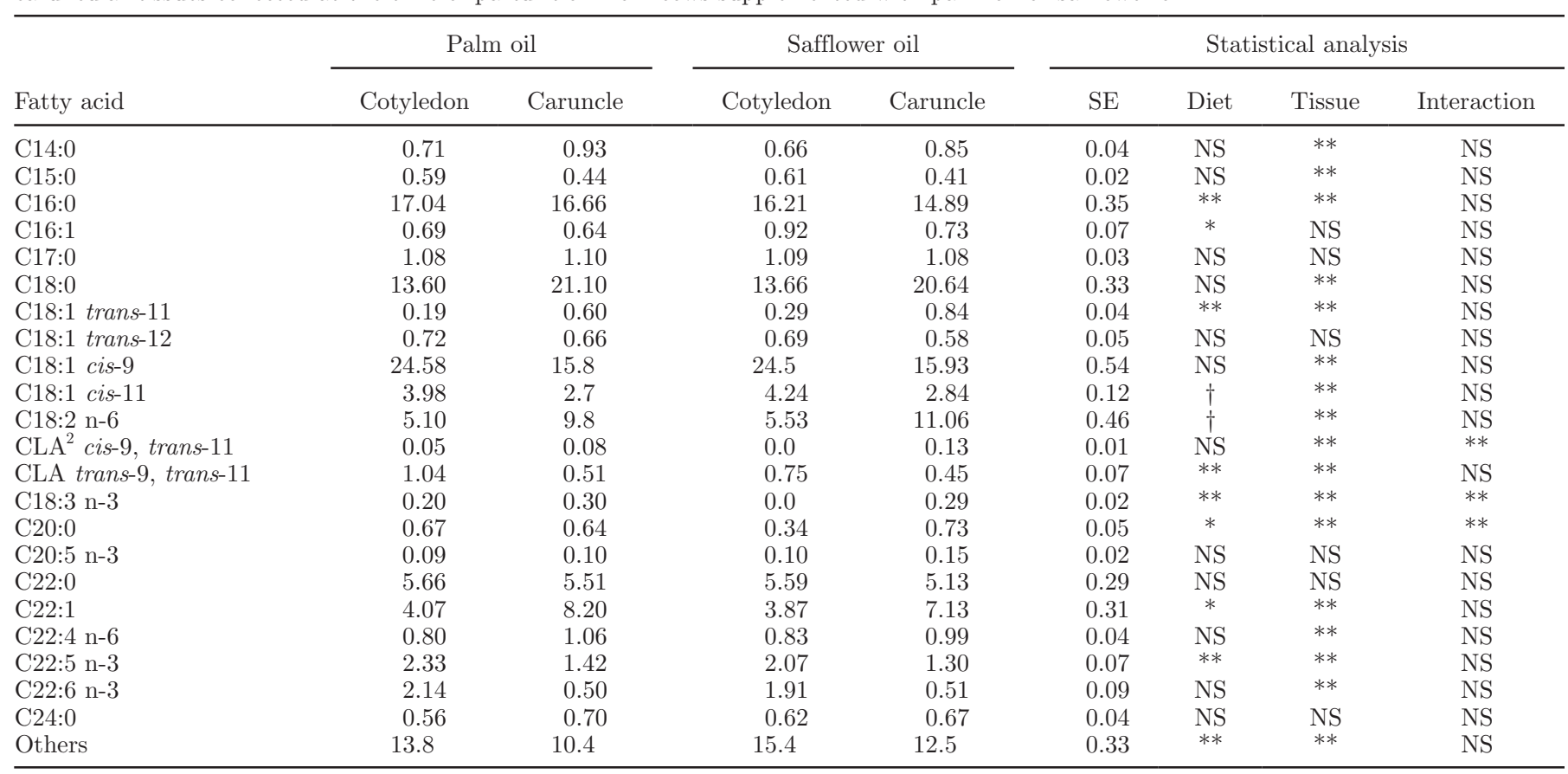

${ }^{1}$ Diets fed from $33 \mathrm{~d}$ prepartum to $30 \mathrm{~d}$ postpartum. Diets contained fat supplements: palm oil (EnerGII) or safflower oil (Prequel 21). All fat supplements were manufactured as Ca salts by Virtus Nutrition, LLC, Corcoran, CA.

${ }^{2}$ Conjugated linoleic acid.

$* P \leq 0.05 ; * * P \leq 0.01 ; \dagger P \leq 0.10$.

$58.6 \pm 5.3 \mathrm{mg} / 100 \mathrm{~mL}$ ) were not different between cows fed $\mathrm{PO}$ or $\mathrm{SO}$ in transition diets, respectively. However, NEFA and BHBA increased $(P<0.01)$, whereas glucose and BUN decreased after parturition $(P<0.01)$.

\section{First Service Pregnancy per Al}

Transition and breeding diets did not affect the proportion of cyclic cows. However, the proportion of cyclic cows was less $(P<0.01)$ in primiparous $(70 \%, \mathrm{n}$ $=266 / 380)$ than in multiparous $(85.2 \%, \mathrm{n}=628 / 737)$ cows; in cows with a purulent $(71.8 \%, \mathrm{n}=189 / 263)$ compared with clear, flecks, and mucopurulent $(84.2 \%$, $\mathrm{n}=567 / 673)$ cervical discharges; and in cows with a BCS of 2.0 to $2.75(77.4 \%, \mathrm{n}=566 / 731)$ compared with those with a BCS of 3.0 to $3.75(85.4 \%, \mathrm{n}=327 / 383)$. Transition and breeding diets did not affect $\mathrm{P} / \mathrm{AI}$ at 32 and $60 \mathrm{~d}$ after TAI (Table 8). Pregnancy loss from d 32

Table 7. Least squares means and pooled SE for total fatty acids (g/100 g of freeze-dried tissue) and different fatty acid percentages (\% of the total fatty acid; $\mathrm{g} / 100 \mathrm{~g}$ of fatty acids) in the cotyledon and caruncle tissues collected at the time of parturition for cows supplemented with palm oil or safflower oil ${ }^{1}$

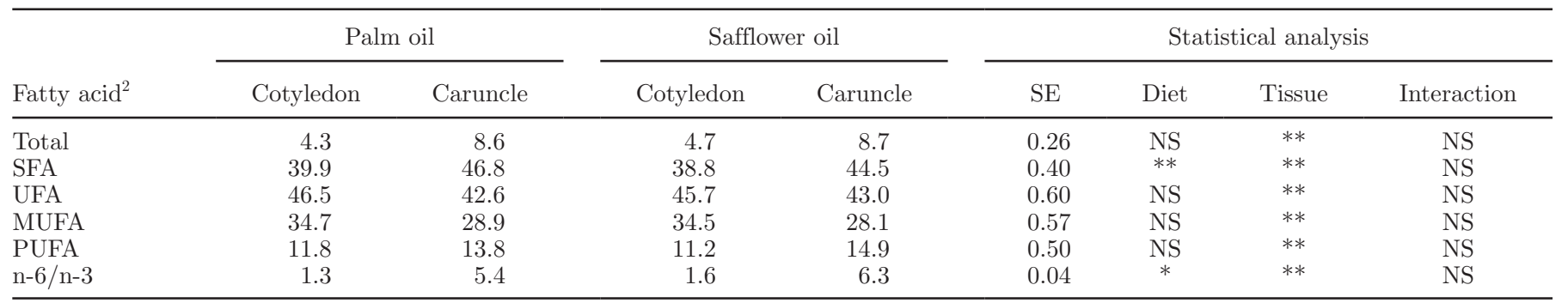

${ }^{1}$ Diets fed from $33 \mathrm{~d}$ prepartum to $30 \mathrm{~d}$ postpartum. Diets contained fat supplements: palm oil (EnerGII) or safflower oil (Prequel 21). All fat supplements were manufactured as calcium salts by Virtus Nutrition, LLC, Corcoran, CA.

${ }^{2} \mathrm{SFA}=$ saturated fatty acids; UFA $=$ unsaturated fatty acids; MUFA = monounsaturated fatty acids; PUFA = polyunsaturated fatty acids; $\mathrm{n}-6 / \mathrm{n}-3=(\mathrm{C} 18: 2+\mathrm{C} 22: 4) /(\mathrm{C} 18: 3+\mathrm{C} 20: 5+\mathrm{C} 22: 6)$.

${ }^{*} P \leq 0.05 ; * P \leq 0.01$. 
Table 8. First, second, and accumulated pregnancy (\% and number of cows) per AI at 32 and $60 \mathrm{~d}$ after AI and pregnancy loss of cows fed fat supplements in 4 different sequences

\begin{tabular}{|c|c|c|c|c|c|c|c|}
\hline \multirow[b]{2}{*}{ AI } & \multicolumn{4}{|c|}{$\operatorname{Diet}^{1}$} & \multicolumn{3}{|c|}{$\operatorname{Diet}_{\text {contrast }}{ }^{2}(P$-value $)$} \\
\hline & $\mathrm{PO}-\mathrm{PO}$ & $\mathrm{SO}-\mathrm{PO}$ & $\mathrm{PO}-\mathrm{FO}$ & $\mathrm{SO}-\mathrm{FO}$ & $\mathrm{C} 1$ & $\mathrm{C} 2$ & C3 \\
\hline \multicolumn{8}{|c|}{ First AI } \\
\hline d 32 & $38.7(107 / 276)$ & $35.8(96 / 268)$ & $39.1(103 / 263)$ & $35.8(89 / 248)$ & NS & NS & NS \\
\hline d 60 & $33.7(92 / 273)$ & $29.7(79 / 266)$ & $37.0(97 / 262)$ & $32.8(81 / 247)$ & NS & NS & NS \\
\hline Loss & $11.5(12 / 104)$ & $15.9(15 / 94)$ & $4.9(5 / 102)$ & $7.9(7 / 88)$ & NS & $<0.05$ & NS \\
\hline \multicolumn{8}{|c|}{ Second AI } \\
\hline Loss & $5.0(2 / 40)$ & $10.0(4 / 38)$ & $7.1(3 / 42)$ & $4.6(3 / 65)$ & NS & NS & NS \\
\hline \multicolumn{8}{|l|}{ All AI } \\
\hline d 32 & $54.4(152 / 279)$ & $50.5(138 / 273)$ & $53.8(147 / 273)$ & $59.5(154 / 259)$ & NS & NS & 0.10 \\
\hline d 60 & $48.3(132 / 273)$ & $42.5(114 / 268)$ & $50.3(136 / 270)$ & $55.4(143 / 258)$ & NS & $<0.01$ & 0.07 \\
\hline Loss & $9.6(14 / 146)$ & $14.3(19 / 133)$ & $5.5(8 / 144)$ & $6.5(10 / 153)$ & NS & $<0.01$ & NS \\
\hline
\end{tabular}

${ }^{1}$ PO (palm oil; EnerGII); SO (safflower oil; Prequel 21); FO (fish oil; StrataG). All fat supplements were manufactured as calcium salts by Virtus Nutrition, LLC, Corcoran, CA.

${ }^{2}$ Contrasts are $\mathrm{C} 1$ (transition diets; $\mathrm{PO}-\mathrm{PO}+\mathrm{PO}-\mathrm{FO}$ vs. SO-PO + SO-FO); C2 (breeding diets; PO-PO + SO-PO vs. $\mathrm{PO}-\mathrm{FO}+\mathrm{SO}-\mathrm{FO}$ ); and $\mathrm{C} 3$ (interaction of diets; $\mathrm{PO}-\mathrm{PO}+\mathrm{SO}-\mathrm{FO}$ vs. PO-FO + SO-PO). NS = nonsignificant.

to 60 after first TAI was less $(P<0.05)$ for cows fed FO compared with that of cows fed PO (Table 8).

\section{Second Service Pregnancy per Al}

Breeding diet altered $(P<0.05) \mathrm{P} / \mathrm{AI}$ at $\mathrm{d} 32$ and a tendency $(P=0.10)$ for a dietary interaction was detected between transition and breeding diets (Table 8). The increase in $\mathrm{d} 32 \mathrm{P} / \mathrm{AI}$ caused by feeding $\mathrm{FO}$ was greater in cows fed the transition diet containing $\mathrm{SO}$, whereas no increase in $\mathrm{P} / \mathrm{AI}$ in cows fed the PObreeding diet was found, regardless of transition diet (Table 8). Likewise, a similar transition by breeding diet interaction $(P<0.05)$ was detected for the $60 \mathrm{~d}$ $\mathrm{P} / \mathrm{AI}$ response (Table 8). A smaller proportion of cows was inseminated for the second TAI during the cool season $(31.9 \%, 193 / 604)$ than during the warm season $(68 \%, 411 / 604)$. Pregnancies per AI examined at d 32 $(28.9 \%, 119 / 411$; and $38.3 \%, 74 / 192)$ and $60(26.0 \%$, $105 / 403$; and $35.2 \% 68 / 193)$ after TAI were fewer $(P$ $<0.01$ ) for cows inseminated during the warmer season than during the cooler season, respectively.

An interaction of transition and breeding diets by season $(P<0.05)$ was detected for second service $\mathrm{P} /$ AI. The interaction of transition and breeding diets by season was associated with a differential effect of FO- and PO-breeding diets fed during the warm season compared with those fed during the cool season for $\mathrm{d}$ 32 and 60 (Figure 3) of pregnancy. Fish oil fed during the warm season had a stimulatory effect on $\mathrm{P} / \mathrm{AI}$ for the second $\mathrm{AI}$ if fed following SO-feeding in the transition period, whereas PO fed in the breeding period had no beneficial effect, and even a slightly negative effect, on $\mathrm{P} / \mathrm{AI}$ for the second AI following SO-feeding in the transition period (Figure 3). During the cool season, breeding diet differences were minimal, regardless of whether $\mathrm{PO}$ or $\mathrm{SO}$ were fed during the transition period for $\mathrm{d} 32$ and 60 (Figure 3 ) of pregnancy. Pregnancy loss from d 32 to 60 after the second TAI $(6.5 \%, 12 / 185)$ was not affected by any variables, including transition and breeding diets (Table 8).

\section{Accumulated Proportion Pregnant}

Accumulated proportion pregnant and pregnancy loss comprised the total pregnancies examined following the first and second AI. Analyses were conducted

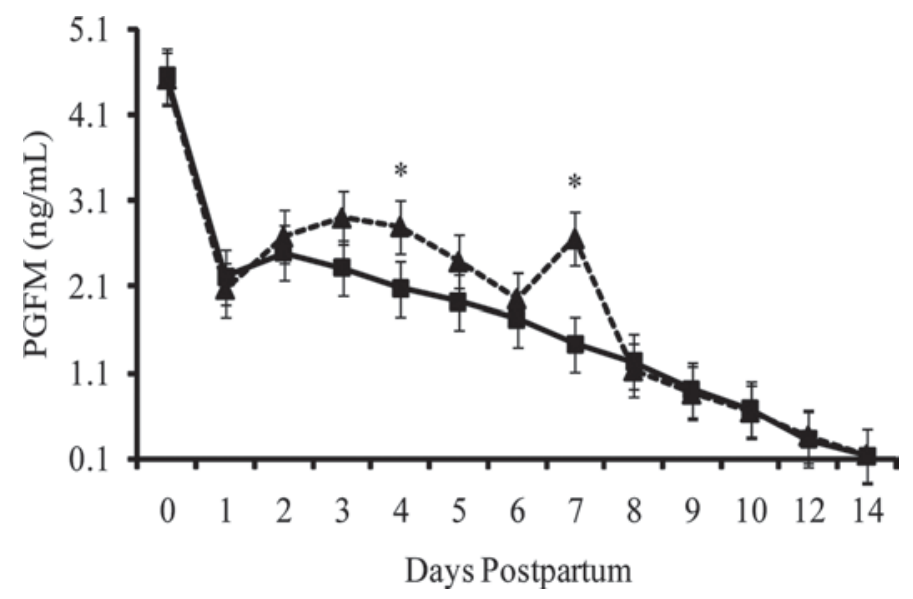

Figure 2. Least squares means $( \pm \mathrm{SE})$ for plasma concentrations of 15-keto-13,14-dihydro-prostaglandin- $\mathrm{F}_{2 \alpha}$ metabolite (PGFM) for the first $14 \mathrm{~d}$ postpartum in a subsample of cows fed Ca salts of palm oil $(-; \mathrm{n}=15)$ or safflower oil $(---; \mathrm{n}=17)$ during the prepartum period (at least $20 \mathrm{~d}$ ) to $35 \mathrm{~d}$ postpartum. ${ }^{*} P<0.05$. 

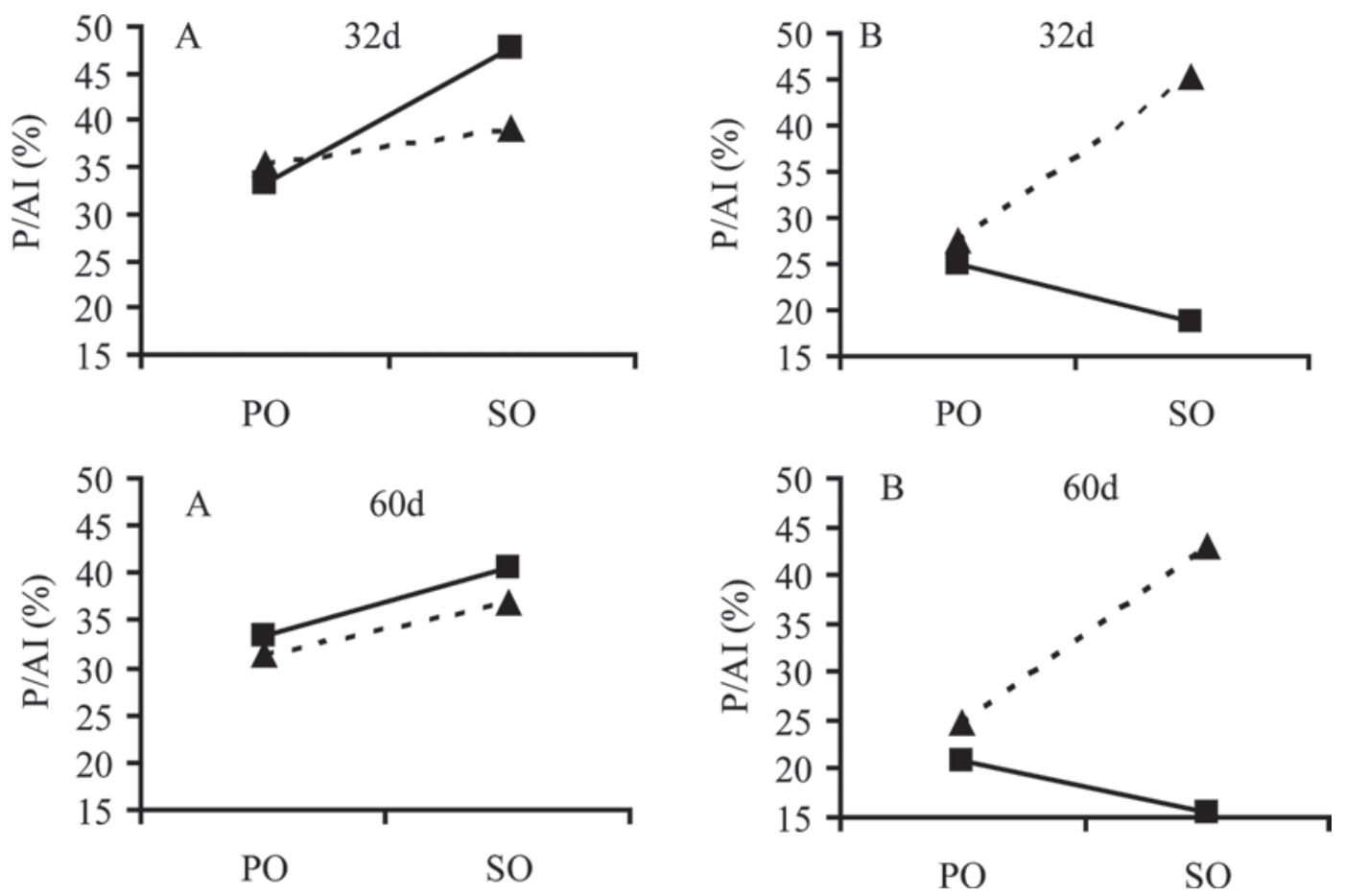

Figure 3. Interaction of transition and breeding diets by season $(P<0.05)$ for proportion of second service pregnancy per AI $(\mathrm{P} / \mathrm{AI})$ examined at 32 and $60 \mathrm{~d}$ after timed AI. Transition diets are shown on the $\mathrm{x}$-axis (PO, palm oil; SO, safflower oil); symbols indicate breeding diets (PO, palm oil, $\mathbf{\square}$; FO, fish oil, $\mathbf{\Delta}$ ). In A panels, cows were inseminated during the cool season (temperature-humidity index $<72$ ); in B panels, cows were inseminated during the warm season (temperature-humidity index $\geq 72$ ).

only for contrast of diets, because other variables associated with pregnancies were examined separately for the first and second AI. Accumulated proportion pregnant at d 32 after TAI was not affected by transition or breeding diets, but tended to be significant $(P=0.10)$ for the interaction of diets (Table 8). Accumulated proportion pregnant at $60 \mathrm{~d}$ after TAI was not affected by transition diets, but it was greater $(P$ $<0.01$ ) for cows supplemented with FO compared with those supplemented with PO during the breeding period (Table 8$)$, and a tendency $(P=0.07)$ was observed for interaction between transition and breeding diets (Table 8). Accumulated pregnancy losses were not affected by transition diets but were less $(P<0.01)$ in cows supplemented with FO compared with those supplemented with PO (Table 8).

\section{Milk Yield}

Mean milk yield and dpp at test day in the first 5 mo postpartum for combinations of transition and breeding diets were PO-PO $(41.1 \pm 0.6 \mathrm{~kg} / \mathrm{d}$ and $75.2 \pm 0.23$ $\mathrm{dpp} ; \mathrm{n}=295)$, PO-FO $(41.3 \pm 0.7 \mathrm{~kg} / \mathrm{d}$ and $75.1 \pm$ $0.23 \mathrm{dpp} ; \mathrm{n}=280)$, SO-PO $(41.7 \pm 0.6 \mathrm{~kg} / \mathrm{d}$ and 75.5 $\pm 0.23 \mathrm{dpp} ; \mathrm{n}=302)$, and SO-FO $(42.1 \pm 0.7 \mathrm{~kg} / \mathrm{d}$ and $75.0 \pm 0.23 \mathrm{dpp} ; \mathrm{n}=289)$. Average milk yield was affected $(P=0.05)$ by transition diets, such that cows supplemented with SO $(41.9 \pm 0.3 \mathrm{~kg} / \mathrm{d} ; \mathrm{n}=591)$ during the transition period had a greater average milk yield for the 5 mo postpartum compared with that of cows fed PO (41.2 $\pm 0.3 \mathrm{~kg} / \mathrm{d} ; \mathrm{n}=575)$. Average milk yield was not affected by breeding diet or the interaction between transition and breeding diets.

\section{DISCUSSION}

Supplementation during the transition period of CS of FA enriched in linoleic acid resulted in sporadic increases in plasma concentrations of PGFM, did not improve uterine health at 8 to $10 \mathrm{dpp}$, but increased milk yield. After $30 \mathrm{dpp}$, supplementation of CS of FA enriched in FA of the n-3 family, decreased pregnancy loss from the first AI, increased second service P/AI, and increased the accumulated proportion of pregnant cows after the first 2 postpartum AI, particularly when cows were fed $\mathrm{SO}$ in the transition period. The combination of feeding additional n- 6 FA during the transition period, followed by feeding additional n-3 FA during the breeding period, represented the best combination of FA supplementation for dairy cows in the current study.

The CS of the PO supplement were comprised of small concentrations of n- 6 and n-3 FA, allowing for a suitable comparison with the $\mathrm{CS}$ of $\mathrm{SO}$, which con- 
tained a high concentration of linoleic acid, and CS of FO-enriched fat, which supplied significant amounts of n-3 FA. Based on group DMI and FA profile of the TMR, estimated average intakes of linoleic acid for PO- and SO-fed cows were 189 and $268 \mathrm{~g} / \mathrm{d}$ during the prepartum period and 282 and $454 \mathrm{~g} / \mathrm{d}$ during the first 30 dpp, respectively. Likewise, intake of EPA and DHA increased from 0 to $20 \mathrm{~g} / \mathrm{d}$ when FO replaced PO in the diet during the breeding period.

The greater proportion of linoleic acid in the SO supplement during the prepartum period resulted in a greater incorporation of this FA into maternal caruncular tissues. The absence of detectable concentrations of arachidonic acid in the caruncular tissue (Table 6) agrees with the findings of Mattos et al. (2004) and may reflect a continual turnover of arachidonic acid for the extensive synthesis and secretion of $\mathrm{PGF}_{2 \alpha}$, characteristic of the immediate postpartum period of dairy cows (Guilbault et al., 1984). The greater content of linoleic acid in the caruncles of SO- supplemented cows may result in a greater availability of linoleic acid as a precursor for synthesis of arachidonic acid and eicosanoids. Clearly, the endometrium of lactating dairy cows contains arachidonic acid on d 17 of the estrous cycle (approximately $15.3 \mathrm{~g} / 100 \mathrm{~g}$ of FA; Bilby et al., 2006) when $\mathrm{PGF}_{2 \alpha}$ secretion is much less than during the periparturient period.

Other studies have reported increased plasma concentrations of PGFM in the first 10 dpp in dairy cows (Cullens, 2005) and at the first day postpartum in primiparous dairy cows (Juchem et al., 2010) when fed supplemental linoleic acid. Significant increases in plasma PGFM concentrations associated with SO supplementation occurred on 4 and $7 \mathrm{dpp}$, but no overall sustained difference was detected. Furthermore, increased secretion of PGFM was associated with greater neutrophil responses (i.e., bactericidal activity and presence of adhesion molecules) in cows supplemented with SO during this time period (4 and $7 \mathrm{dpp}$; Silvestre et al., in press). Indeed, these responses are known to be stimulated by arachidonic acid products such as $\mathrm{PGF}_{2 \alpha}$ (Badwey et al., 1981, 1984; Hardy et al., 1991; Poulos et al., 1991) and leukotriene $\mathrm{B}_{4}$ (Jannace et al., 1992).

On the other hand, supplementation of dairy cows with FO has the potential to increase n-3 FA in caruncular (Mattos et al., 2004) and endometrial tissues (Bilby et al., 2006) and attenuate inflammatory responses. This study indicates that dairy cows supplemented with CS of $\mathrm{SO}$ can increase the contents of linoleic acid and the n6:n-3 ratio in caruncular tissue. Therefore, daily feeding of CS of FA can strategically affect tissue FA content.

The caruncular total FA content was almost 2-fold greater than that in the cotyledon. The greater and lesser content of oleic acids and linoleic acid, respec- tively, in the cotyledon compared with that in the caruncular tissue is, in part, in agreement with Elmes et al. (2004) who reported much lower concentrations of linoleic acid in the fetal placenta of sheep, represented by the allantochorion compared with those in the caruncle. However, oleic acid was not reported. Feeding SO slightly increased the linoleic acid content and n-6:n-3 ratio of the cotyledon. In the cotyledonary placenta of the cow, the exchange between maternal and fetal circulation occurs in the placentome where maternal caruncular tissues and fetal allantochorion interdigitate. Therefore, FA composition of the placenta is predisposed to changes according to maternal nutrition. Importantly, changes in the $n-6: n-3$ ratio of FA in the diet of cows fed SO or PO did not change gestation lengths either in primiparous or multiparous cows. The desaturation ratio calculated based upon the ratio of C18:1 n-9/C18:0 was greater for the cotyledon (1.80) than for the caruncle (0.76), regardless of diet. The differences between these tissues may indicate a depressed activity of the enzyme $\Delta^{9}$-desaturase in the caruncle tissue, which maintained a greater saturation of FA in this tissue compared with that in the cotyledon. The $\Delta^{9}$-desaturase also converts trans-11 C18:1 to cis-9 trans-11 CLA. The ratio of cis-9 trans-11 CLA: trans-11 C18:1 was 0.26 for cotyledonary tissue from cows fed PO and 0.14 for caruncles coming from cows across diets, which supports an inhibition of desaturase. The calculation was not possible for cotyledonary tissue from cows fed $\mathrm{SO}$ because the concentration of cis-9 trans-11 CLA was $0 \mathrm{~g} / 100 \mathrm{~g}$ of FA.

In this experiment, BCS did not differ between dietary treatments until $43 \mathrm{dpp}$. A greater proportion of cows gained body condition from 43 dpp to first insemination day (i.e., approximately $80 \mathrm{dpp}$ ) when fed FO than when fed PO. Metabolites measured in plasma in a subsample of cows during the postpartum period were not affected by SO or PO transition diets. Metabolic responses are influenced mainly by energy balance, which is represented by the difference in energy consumed minus energy expended for maintenance and lactation. Energy balance becomes negative during the transition period, starting just before parturition and reaching a maximum nadir in the first week after parturition (Grummer, 1995). The degree of negative energy balance in the postpartum period depends on body condition at parturition and the degree in reduction of intake (Garnsworthy and Topps, 1982). The frequency distribution of cows among the body condition scores was the same for the subsample of cows used for metabolite measurements. Moreover, the energy content of the transition diets was the same.

The proportions of cows with clear, flecks, mucopurulent, or purulent discharges were not different between 
dietary treatments. Juchem et al. (2010) reported that feeding of CS of linoleic and trans-octadecenoic acids during the transition period reduced the incidence of puerperal metritis. Indeed, cows with greater PGFM concentrations during the first $5 \mathrm{dpp}$ had a lesser risk of metritis (Seals et al., 2002; Silvestre et al., 2009).

The proportion of cows cycling was not affected by transition or breeding diets. Cows with purulent discharge in the early postpartum period had a greater frequency of anestrus. Also, the proportion of cows cycling was lower when BCS was less than 3.0 at 43 dpp. The association of uterine bacterial infection on d 7 postpartum was associated with delayed first postpartum ovulation (Sheldon et al., 2002; Williams et al., 2007) and a negative association between BCS and the incidence of anovulatory/anestrous cows has been reported (Moreira et al., 2001; Santos et al., 2004). The energy status of dairy cows affects resumption of ovarian cycles, and BCS is an indicator of body reserves, mostly body fat, in dairy cows (Ferguson et al., 1994).

In the present study, the response to feeding FO differed between the first and second postpartum AI. Pregnancy per AI increased with feeding FO at the second postpartum AI, whereas maintenance of pregnancy was improved by FO in the first postpartum AI. Taken together, feeding FO improved the accumulated proportion of pregnant cows following the first 2 postpartum inseminations. Differences in the nature of reproductive benefits could have resulted from different durations of FA supplementation, $90 \mathrm{~d}$ for the second AI compared with $50 \mathrm{~d}$ for the first AI. However, a 50-d feeding period for $\mathrm{FO}$ was sufficient to change the profile of n-3 FA in the uterus at $17 \mathrm{~d}$ of cycle (Bilby et al., 2006).

Feeding fish meal improved the proportion of pregnant cows in several studies (Armstrong et al., 1990; Carroll et al., 1994; Burke et al., 1997). Also, Petit and Twagiramungu (2006) reported that embryonic mortality between d 30 to 50 post-insemination tended to decrease in cows that consumed linseed (i.e., n-3 enriched) compared with that in cows that consumed CS of PO.

Up to $40 \%$ of total embryonic losses are estimated to occur between d 8 and 17 of pregnancy (Thatcher et al., 1994). This high proportion of losses precedes or occurs concurrently with the period when the embryo inhibits uterine $\mathrm{PGF}_{2 \alpha}$ secretion. Thus, some loss may occur because nonviable or undersized embryos are unable to inhibit secretion of $\mathrm{PGF}_{2 \alpha}$. The ability of $\mathrm{n}-3$ FA supplements to delay luteolysis has been proposed as a potential method of improving cattle fertility by giving the conceptus a longer period to develop before the onset of luteolysis (Mattos et al., 2004). Therefore, strategies to partially inhibit secretion of $\mathrm{PGF}_{2 \alpha}$ may increase pregnancy rates and embryonic survival. Mat- tos et al. (2000) suggested that feeding fish meal could reduce uterine secretion of $\mathrm{PGF}_{2 \alpha}$ that delayed completion of functional luteolysis. Supplementation of n-3 PUFA in the form of FO increased concentrations of EPA and DHA in caruncular (Mattos et al., 2004) and endometrial (Bilby et al., 2006) tissues. The greater availability of these FA in the uterus can competitively inhibit the oxygenation of arachidonic acid by cyclooxygenase and, therefore, decrease the synthesis of $\mathrm{PGF}_{2 \alpha}$ (Mattos et al., 2003, 2004), leading to increased synthesis of prostanoids of the 3 series at the expense of the prostanoids of the 2 series. Prostanoids of the 3 series are less bioactive (Needleman et al., 1979), and there appears to be no evidence for their role in ruminant luteolysis. Prostaglandin $\mathrm{F}_{3 \alpha}$ has only a $25 \%$ affinity for the ovine luteal receptor compared with that of $\mathrm{PGF}_{2 \alpha}$ (Balapure et al., 1989).

The greater P/AI at 30 and $60 \mathrm{~d}$ after the second service for FO-fed cows was detected partially during the warm season of the year and appeared to be preferentially beneficial when FO-supplemented cows were fed SO during the transition period before FO feeding (i.e., transition and breeding diet by season interaction). One possibility contributing to the interaction with season was that fewer cows received their second AI during the cool season $(\mathrm{n}=193)$ than during the warm season $(\mathrm{n}$ $=411$ ) of the year. In parallel, most early embryonic mortality associated with the warm season occurred between d 6 and 14 of pregnancy (Ryan et al., 1993) or within $7 \mathrm{~d}$ after insemination when experimental application of a heat stress caused rectal temperature to rise to $41.1^{\circ} \mathrm{C}$ (Putney et al. 1989). Indeed, the effects of FO on fertility in the second AI were observed by d 32 after TAI, with no changes in maintenance of pregnancy between 32 and $60 \mathrm{~d}$ of gestation.

Greater second service P/AI and fewer pregnancy losses at first AI in cows supplemented with FO were also associated with less TNF- $\alpha$ production when neutrophils were stimulated with LPS in a subsample of cows around the time of insemination (Silvestre et al., in press). An immunological suppression or tolerance is present during pregnancy. The fetus and fetal component of the placental unit is an allograft that needs to avoid rejection by the maternal unit for the duration of pregnancy (Siiteri and Stites, 1982). Maintenance of an immunologically favorable, immunosuppressive environment in the uterus is needed for embryo survival (Raghupathy, 2001; Hunt et al., 2005). An immune response to a foreign body starts with the induction of an inflammatory response that is amplified by cytokines produced by cells (i.e., epithelial cells, macrophages, and later neutrophils) in the vicinity of the foreign body. Because cytokine production of neutrophils is less in FO-fed cows, perhaps there is an overall lower 
inflammatory response of the cows occurs that could enhance tolerance to the embryo/fetal-placental units. Indeed, the localized released of IFN- $\tau$ by the trophectoderm and the production of progesterone by the corpus luteum creates an anti-inflammatory environment, contributing to immune tolerance. For example, progesterone, through the actions of uterine serpins, can reduce lymphocyte proliferation (Tekin et al., 2005) and progesterone itself can reduce the production of reactive oxygen species by macrophages (Siiteri and Stites, 1982). Additionally, it is currently believed that for the continuous normal development of pregnancy, production of pro-inflammatory cytokines (i.e., IL-2, tumor necrosis factor- $\alpha$, and IFN- $\gamma$ ) should be suppressed, whereas production of anti-inflammatory cytokines (i.e., IL-4, IL-6, and IL-10) should be enhanced (Wegmann et al., 1993). Immune cells, especially the macrophages, are a major source of cytokines and growth factors and they contribute to the maintenance of the adequate balance between pro- and anti-inflammatory cytokines at the placental bed. Inappropriate activation or accumulation of endometrial macrophages is associated with pregnancy loss (Haddad et al., 1997) and reduced trophoblast invasiveness (Reister et al., 2001). The inhibitory actions of progesterone and anti-inflammatory cytokines are believed to represent an important mechanism by which the allogenic conceptus escapes graft rejection by the maternal immune system.

The greatest accumulated proportion of pregnant cows following the 2 postpartum inseminations was observed in cows with a sequential supplementation consisting of SO during the transition period followed by FO fed in the breeding period. The pro-inflammatory state induced by feeding SO enhanced numerous aspects of neutrophil physiology and augmented a greater acute phase response of tissues (Silvestre et al., in press). Once parturition occurs, the innate immune competence of the uterus must be restored to successfully reject remaining placental tissues and to prevent ascendant bacterial growth.

Cows supplemented with SO compared with those supplemented with PO during the transition period produced more milk during the 5-mo period of lactation. Chouinard et al. (1998) reported that milk yield increased linearly as degree of unsaturation of the dominant FA in the CS of FA increased, such that soybean (54\% linoleic acid) and linseed oil ( $51 \% \alpha$-linolenic acid) had the highest milk yields and lower milk fat content (Chouinard et al., 1998). However, feeding a CS of PO at $2.2 \%$ of dietary DM postpartum also improved milk yield compared with that from no fat supplementation (Garcia-Bojalil et al., 1998). No increase in the overall milk yield was observed during the entire period of FO feeding. No effects on milk yield by adding FO to diets have been reported (Spain et al., 1995; AbuGhazaleh et al., 2002; Mattos et al., 2002), whereas others have reported increases in milk yield when fed at earlier stages of lactation (Keady et al., 2000; Bilby et al., 2006; Moussavi et al., 2007).

In conclusion, strategic feeding of FA can affect tissue FA composition. Feeding supplements rich in linoleic acid during the transition period improved milk yield. Following the transition period, feeding CS rich in EPA and DHA during the breeding period may play an important role in regulating the endometrium to support pregnancy, as demonstrated by the decreased pregnancy loss after first $\mathrm{AI}$ and increased $\mathrm{P} / \mathrm{AI}$ after the second AI. This beneficial effect of feeding CS of FA enriched in EPA and DHA was augmented when CS of FA enriched in linoleic acid were fed previously in the transition period. Therefore, we propose a strategy of FA supplementation comprised of feeding n-6 FA during the transition period, followed by EPA and DHA in the breeding period to maximize dairy cow production and reproduction.

\section{ACKNOWLEDGMENTS}

The authors express their appreciation to Ron St.John, Peter Gelber, and the staff at Alliance Dairies (Trenton, FL) for expert management of experimental cows. This research was supported partially by grants from Virtus Nutrition Inc. and the National Research Initiative USDA Research Grant \#2004-35203-14137.

\section{REFERENCES}

AbuGhazaleh, A. A., D. J. Schingoethe, A. R. Hippen, K. F. Kalscheur, and L. A. Whitlock. 2002. Fatty acid profiles of milk and rumen digesta from cows fed fish oil, extruded soybeans, or their blend. J. Dairy Sci. 85:2266-2276.

Ambrose, D. J., C. T. Estill, M. G. Colazo, J. P. Kastelic, and R. Corbett. 2006. Conception rates and pregnancy losses in dairy cows fed a diet supplemented with rolled flaxseed. Page 500 in Reproduction in Domestic Ruminants VI. Nottingham University Press, Nottingham, UK.

Armstrong, J. D., E. A. Goodall, F. J. Gordon, D. A. Rice, and W. J. McCaughey. 1990. The effects of levels of concentrate offered and inclusion of maize gluten or fish meal in the concentrate on reproductive performance and blood parameter of dairy cows. Anim. Prod. 50:1-10.

Badwey, J. A., J. T. Curnutte, J. M. Robinson, C. B. Berde, M. J. Karnovsky, and M. L. Karnovsky. 1984. Effects of free FA on release of superoxide and on change of shape by human neutrophils. Reversibility by albumin. J. Biol. Chem. 259:7870-7877.

Badwey, J. A., J. M. Robinson, M. J. Karnovsky, and M. L. Karnovsky. 1981. Superoxide production by an unusual aldehyde oxidase in guinea pig granulocytes. Characterization and cytochemical localization. J. Biol. Chem. 256:3479-3486.

Balapure, A. K., C. E. Rexroad Jr., K. Kawada, D. S. Watt, and T. A. Fitz. 1989. Structural requirements for prostaglandin analog interaction with the ovine corpus luteum prostaglandin $\mathrm{F}_{2 \alpha}$ receptor. Implications for development of a photoaffinity probe. Biochem. Pharmacol. 38:2375-2381.

Bilby, T. R., T. Jenkins, C. R. Staples, and W. W. Thatcher. 2006. Pregnancy, bovine somatotropin, and dietary n-3 fatty acids in 
lactating dairy cows: III. Fatty acid distribution. J. Dairy Sci. 89:3386-3399.

Bruckental, I., D. Drori, M. Kaim, H. Lehrer, and Y. Folman. 1989. Effects of source and level of protein on milk yield and reproductive performance of high-producing primiparous and multiparous dairy cows. Anim. Prod. 48:319-329.

Burke, J. M., C. R. Staples, C. A. Risco, R. L. De La Sota, and W. W. Thatcher. 1997. Effect of ruminant grade menhaden fish meal on reproductive performance of lactating dairy cows. J. Dairy Sci. 80:3386-3398.

Carroll, D. J., F. R. Hossain, and M. R. Keller. 1994. Effect of supplemental fish meal on the lactation and reproductive performance of dairy cows. J. Dairy Sci. 77:3058-3072.

Chouinard, P. Y., V. Girard, and G. J. Brisson. 1998. Fatty acid profile and physical properties of milk fat from cows fed calcium salts of fatty acids with varying unsaturation. J. Dairy Sci. 81:471-481.

Coulombe, J. J., and L. Favreau. 1963. A new simple method for colorimetric determination of urea. Clin. Chem. 9:102-108.

Cullens, F. M. 2005. Effects of the timing of initiation of fat supplementation on productive and reproductive responses of periparturient dairy cows during summer. M.S. Thesis. Univ. FL, Gainesville.

Edmonson, A. J., I. J. Lean, L. D. Weaver, T. Farver, and G. Webster. 1989. A body condition scoring chart for Holstein dairy cows. J. Dairy Sci. 72:68-78.

Elmes, M., P. Tew, Z. Cheng, S. E. Kirkup, D. R. Abayasekara, P. C. Calder, M. A. Hanson, D. C. Wathes, and G. C. Burdge. 2004 The effect of dietary supplementation with linoleic acid to late gestation ewes on the fatty acid composition of maternal and fetal plasma and tissues and the synthetic capacity of the placenta for 2-series prostaglandins. Biochim. Biophys. Acta 1686:139-147.

Ferguson, J. D., D. T. Galligan, and N. Thomsen. 1994. Principal descriptors of body condition score in Holstein cows. J. Dairy Sci. 77:2695-2703.

Fuentes, M. C., S. Calsamiglia, C. Sanchez, A. Gonzalez, J. R. Newbold, J. E. P. Santos, L. M. Rodriguez-Alcala, and J. Fontecha. 2008. Effect of extruded linseed on productive and reproductive performance of lactating dairy cows. Livest. Sci. 113:144-153.

Gajewski, Z., R. Thun, R. Faundez, and Z. Boryczko. 1999. Uterine motility in the cow during puerperium. Reprod. Domest. Anim. 34:185-191.

Garcia-Bojalil, C. M., C. R. Staples, C. A. Risco, J. D. Savio, and W. W. Thatcher. 1998. Protein degradability and calcium salts of long-chain fatty acids in the diets of lactating dairy cows: Productive responses. J. Dairy Sci. 81:1374-1384.

Garnsworthy, P. C., and J. H. Topps. 1982. The effect of body condition of dairy cows at calving on their food intake and performance when given complete diets. Anim. Prod. 35:113-119.

Gochman, N., and J. M. Schmitz. 1972. Application of a new peroxide indicator reaction to the specific automated determination of glucose with glucose oxidase. Clin. Chem. 18:943-950.

Grummer, R. R. 1995. Impact of changes in organic nutrient metabolism on feeding the transition dairy cow. J. Anim. Sci. 73:28202833.

Guilbault, L. A., W. W. Thatcher, M. Drost, and S. M. Hopkins. 1984. Source of $\mathrm{F}$ series prostaglandins during the early postpartum period in cattle. Biol. Reprod. 31:879-887.

Haddad, E. K., A. J. Duclos, W. S. Lapp, and M. G. Baines. 1997. Early embryo loss is associated with the prior expression of macrophage activation markers in the decidua. J. Immunol. 158:4886-4892.

Hammon, D. S., I. M. Evjen, T. R. Dhiman, J. P. Goff, and J. L. Walters. 2006. Neutrophil function and energy status in Holstein cows with uterine health disorders. Vet. Immunol. Immunopathol. 113:21-29.

Hardy, S. J., B. S. Robinson, A. Poulos, D. P. Harvey, A. Ferrante, and A. W. Murray. 1991. The neutrophil respiratory burst. Responses to FA, N-formylmethionylleucylphenylalanine and phorbol ester suggest divergent signalling mechanisms. Eur. J. Biochem. 198:801-806

Hoedemaker, M., L. A. Lund, and W. C. Wagner. 1992. Influence of arachidonic acid metabolites and steroids on function of bovine polymorphonuclear neutrophils. Am. J. Vet. Res. 53:1534-1539.
Hunt, J. S., M. G. Petroff, R. H. McIntire, and C. Ober. 2005. HLA-G and immune tolerance in pregnancy. FASEB J. 19:681-693.

Jannace, P. W., R. H. Lerman, J. I. Santos, and J. J. Vitale. 1992. Effects of oral soy phosphatidylcholine on phagocytosis, arachidonate concentrations, and killing by human polymorphonuclear leukocytes. Am. J. Clin. Nutr. 56:599-603.

Jenkins, T. C. 2010. Common analytical errors yielding inaccurate results during analysis of fatty acids in feed and digesta samples. J. Dairy Sci. 93:1170-1174.

Johnson, H. D. 1976. World climate and milk production. Int. J. Biometeorol. 6(2 Suppl):171-180.

Johnson, M. M., and J. P. Peters. 1993. Technical note: An improved method to quantify non-esterified fatty acids in bovine plasma. J. Anim. Sci. 71:753-756.

Juchem, S. O., R. L. Cerri, M. Villaseñor, K. N. Galvão, R. G. Bruno, H. M. Rutigliano, E. J. DePeters, F. T. Silvestre, W. W. Thatcher, and J. E. Santos. 2010. Supplementation with calcium salts of linoleic and trans-octadecenoic acids improves fertility of lactating dairy cows. Reprod. Domest. Anim. 45:55-62.

Keady, T. W., C. S. Mayne, and D. A. Fitzpatrick. 2000. Effects of supplementation of dairy cattle with fish oil on silage intake, milk yield and milk composition. J. Dairy Res. 67:137-153.

Kimura, K., J. P. Goff, and M. E. Jr. Kehrli. 1999. Effects of the presence of the mammary gland on expression of neutrophil adhesion molecules and myleoperoxidase activity in periparturient dairy cows. J. Dairy Sci. 82:2385-2392.

Kimura, K., J. P. Goff, M. E. Jr. Kehrli, and T. A. Reinhardt. 2002. Decreased neutrophil function as a cause of retained placenta in dairy cattle. J. Dairy Sci. 85:544-550.

Mattos, R., A. Guzeloglu, L. Badinga, C. R. Staples, and W. W. Thatcher. 2003. Polyunsaturated fatty acids and bovine interferontau modify phorbol ester-induced secretion of prostaglandin F2 alpha and expression of prostaglandin endoperoxide synthase-2 and phospholipase-A2 in bovine endometrial cells. Biol. Reprod. 69:780-787.

Mattos, R., C. R. Staples, A. Arteche, M. C. Wiltbank, F. J. Diaz, T. C. Jenkins, and W. W. Thatcher. 2004. The effects of feeding fish oil on uterine secretion of PGF2 $\alpha$, milk composition, and metabolic status of periparturient Holstein cows. J. Dairy Sci. 87:921-932.

Mattos, R., C. R. Staples, and W. W. Thatcher. 2000. Effects of dietary fatty acids on reproduction in ruminants. Rev. Reprod. 5:38-45.

Mattos, R., C. R. Staples, J. Williams, A. Amorocho, M. A. McGuire, and W. W. Thatcher. 2002. Uterine, ovarian, and production responses of lactating dairy cows to increasing dietary concentrations of menhaden fish meal. J. Dairy Sci. 85:755-764

Moreira, F., C. Orlandi, C. A. Risco, R. Mattos, F. Lopes, and W. W. Thatcher. 2001. Effects of presynchronization and bovine somatotropin on pregnancy rates to a timed artificial insemination protocol in lactating dairy cows. J. Dairy Sci. 84:1646-1659.

Moussavi, A. R.. R. O. Gilbert, T. R. Overton, D. E. Bauman, and W. R. Butler. 2007. Effects of feeding fish meal and n-3 fatty acids on milk yield and metabolic responses in early lactating dairy cows. J. Dairy Sci. 90:136-144.

Needleman, P., A. Raz, M. S. Minkes, J. A. Ferrendeli, and H. Sprecher. 1979. Triene prostaglandins: Prostacyclin and thromboxane biosynthesis and unique biological properties. Proc. Natl. Acad. Sci. USA 76:944-948.

NOAA (National Oceanic and Atmospheric Administration). 1976. Livestock hot weather stress. Pages 31-37 in US Department of Commerce, National Weather Service Central Region, Regulatory Operations Manual Letters. US Government Printing Office, Washington, DC.

NRC. 2001. Nutrient Requirements of Dairy Cattle. 7th ed. National Academy of Science, Washington, DC

Petit, H. V., R. J. Dewhurst, J. G. Proulx, M. Khalid, W. Haresign, and H. Twagiramungu. 2001. Milk production, milk composition, and reproductive function of dairy cows fed different fats. Can. J. Anim. Sci. 81:263-271. 
Petit, H. V., and H. Twagiramungu. 2006. Conception rate and reproductive function of dairy cows fed different fat sources. Theriogenology 66:1316-1324.

Poulos, A., B. S. Robinson, A. Ferrante, D. P. Harvey, S. J. Hardy, and A. W. Murray. 1991. Effect of 22-32 carbon n-3 polyunsaturated FA on superoxide production in human neutrophils: Synergism of docosahexaenoic acid with f-met-leu-phe and phorbol ester. Immunology 73:102-108.

Putney, D. J., M. Drost, and W. W. Thatcher. 1989. Influence of summer heat stress on pregnancy rates of lactating dairy cattle following embryo transfer or artificial insemination. Theriogenology $31: 765-778$.

Raghupathy, R. 2001. Pregnancy: Success and failure within the Th1/ Th2/Th3 paradigm. Semin. Immunol. 13:219-227.

Reister, F., H. G. Frank, J. C. Kingdom, W. Heyl, P. Kaufmann, W. Rath, and B. Huppertz. 2001. Macrophage-induced apoptosis limits endovascular trophoblast invasion in the uterine wall of preeclamptic women. Lab. Invest. 81:1143-1152.

Ryan, D. P., J. F. Prichard, E. Kopel, and R. A. Godke. 1993. Comparing early embryo mortality in dairy cows during hot and cool seasons of the year. Theriogenology 39:719-737.

Santos, J. E., S. O. Juchem, R. L. Cerri, K. N. Galvão, R. C. Chebel, W. W. Thatcher, C. S. Dei, and C. R. Bilby. 2004. Effect of bST and reproductive management on reproductive performance of Holstein dairy cows. J. Dairy Sci. 87:868-881.

Seals, R. C., I. Matamoros, and G. S. Lewis. 2002. Relationship between postpartum changes in 13, 14-dihydro-15-keto-PGF - $_{2 \alpha}$ concentrations in Holstein cows and their susceptibility to endometritis. J. Anim. Sci. 80:1068-1073.

Sheldon, I. M., D. E. Noakes, A. N. Rycroft, D. U. Pfeiffer, and H. Dobson. 2002. Influence of uterine bacterial contamination after parturition on ovarian dominant follicle selection and follicle growth and function in cattle. Reproduction 123:837-845.

Siiteri, P. K., and D. P. Stites. 1982. Immunologic and endocrine interrelationships in pregnancy. Biol. Reprod. 26:1-14.

Silvestre, F. T., T. S. M. Carvalho, C. Crawford, J. E. P. Santos, C. R. Staples, T. Jenkins, and W. W. Thatcher. Effects of differential supplementation of fatty acids during the peripartum and breeding periods of Holstein cows: II. Acute phase proteins, and neutrophil fatty acids and function. J. Dairy Sci. (in press); 10.3168/ jds.2010-3371

Silvestre, F. T., C. A. Risco, M. Lopez, M. J. de Sá, T. R. Bilby, and W. W. Thatcher. 2009. Use of increasing doses of a degradable Deslorelin implant to enhance uterine involution in postpartum lactating dairy cows. Anim. Reprod. Sci. 116:196-212.

Spain, J. N., C. E. Polan, and B. A. Watkins. 1995. Evaluating effects of fish meal on milk fat yield of dairy cows. J. Dairy Sci. 78:1142-1153.

Staples, C. R., W. W. Thatcher, and J. H. Clark. 1990. Relationship between ovarian activity and energy status during the early postpartum period of high producing dairy cows. J. Dairy Sci. 73:938-947.

Tekin, S., M. B. Padua, and P. J. Hansen. 2005. Antiproliferative actions of ovine uterine serpin. Am. J. Reprod. Immunol. 53:136 143.

Thatcher, W. W., C. R. Staples, G. Danet-Desnoyers, B. Oldick, and E.-P. Schmitt. 1994. Embryo health and mortality in sheep and cattle. J. Anim. Sci. 72(Suppl. 3):16-30.

Weber, P. S., S. A. Madsen, G. W. Smith, J. J. Ireland, and J. L. Burton. 2001. Pre-translational regulation of neutrophil CD62L in glucocorticoid-challenged cattle . Vet. Immunol. Immunopathol. $83: 213-240$

Wegmann, T. G., H. Lin, L. Guilbert, and T. R. Mosmann. 1993. Bidirectional cytokine interactions in the maternal-fetal relationship: Is successful pregnancy a TH2 phenomenon? Immunol. Today $14: 353-356$

West, J. W. 2003. Effects of heat-stress on production in dairy cattle. J. Dairy Sci. 86:2131-2144.

Williams, E. J., D. P. Fischer, D. E. Noakes, G. C. England, A. Rycroft, H. Dobson, and I. M. Sheldon. 2007. The relationship between uterine pathogen growth density and ovarian function in the postpartum dairy cow. Theriogenology 68:549-559. 